\title{
Development of an AHP hierarchy for managing omnichannel capabilities: a design science research approach
}

\author{
Jochen Wulf ${ }^{1}$ (iD
}

Received: 5 March 2018/Accepted: 26 February 2019/Published online: 12 March 2019

(C) The Author(s) 2019

\begin{abstract}
Because of the importance of omnichannel services in today's consumer markets, B2C organizations have a high demand for management instruments that support the organizational development of omnichannel capabilities. Prior literature acknowledges that the shift to omnichannel paradigm demands not only technological modifications but also an organizational transformation. However, it remains unclear which capabilities an organization requires and how they can be developed. We address this research gap and construct an analytic hierarchy process (AHP) hierarchy by applying design science research methodology. The developed AHP hierarchy supports capability management in the knowledge acquisition phase. The availability of this hierarchy further is a precondition for implementing an AHP method that supports the selection and steering of projects for omnichannel capability development or the comparison of organizations' capability maturities. We conduct a hierarchy construction procedure that includes various qualitative research methods (focus group, cross-interview analysis, multiple case studies). We demonstrate and evaluate the AHP hierarchy at a global automobile manufacturer, which involved in-depth interviews and a workshop with six executive managers. With our results, we contribute to research on omnichannel management by introducing an instrument that supports omnichannel capability management in B2C organizations during the knowledge acquisition phase.
\end{abstract}

Keywords Omnichannel management · Organizational capabilities · Capability model · Analytical hierarchy process $\cdot$ AHP hierarchy $\cdot$ Design science research

Jochen Wulf

jochen.wulf@unisg.ch

1 University of St. Gallen, Müller-Friedberg-Strasse 8, 9000 St. Gallen, Switzerland 


\section{Introduction}

Business-to-consumer (B2C) firms are facing significant shifts in consumer behavior. Many consumers ${ }^{1}$ today switch between different channels and demand a consistent experience along the customer journey, including for instance the ability to check in-store availability online (Gallino and Moreno 2014; Blom et al. 2017; McPartlin and Feigen Dugal 2012). Further, customers increasingly use multiple channels conjunctively, e.g. by using mobile service to compare prices instore ('showrooming') or by ordering alternative products into a store ('webrooming') (Brynjolfsson et al. 2013; Flavián et al. 2016; Krueger 2015). These developments have a strong impact on the business models and competitive environments of B2C service providers and herald the start of an omnichannel paradigm that among others influences product assortment, supply chain design, and pricing; thus, B2C service providers require novel organizational capabilities (Brynjolfsson et al. 2013; Leeflang et al. 2014; Parise et al. 2016; Hübner et al. 2016a). For example, technology innovations for consumer identification and tracking must be embraced because many consumers demand personal content (Klena and Van Tine 2014). However, many service providers currently fail to satisfy consumer demands for omnichannel services (Accenture 2013; Consumers 2016). Consequently, providers of B2C services are in urgent need to improve omnichannel capabilities and require assisting management instruments (Econsultancy 2013; Frost \& Sullivan 2015; Lauchlan 2017a, b; Ovum 2017).

Omnichannel management is the synergetic management of channels and consumer touchpoints with the objective to optimize consumer experience and channel performance (Verhoef et al. 2015). In contrast to more traditional channel management approaches, the omnichannel paradigm requires $\mathrm{B} 2 \mathrm{C}$ service providers to broadly provision and integrate customer channels, to cover the complete customer lifecycle, and to implement an overarching approach to channel coordination (Verhoef et al. 2015; Beck and Rygl 2015; Picot-Coupey et al. 2016). The literature on organizational capabilities largely lacks modeling approaches with well-defined constructs and a formalized capability structure, which are well-known enablers of capability management (Rauffet et al. 2016). Further, prior literature produces explanatory (e.g. Hansen and Sia 2015) and predictive (e.g. Luo et al. 2016) theories. However, there is a lack of theory for design and action that addresses urgent management demands to improve omnichannel capabilities (Econsultancy 2013; Frost \& Sullivan 2015; Ovum 2017).

In this paper, we address these research gaps and develop an analytic hierarchy process (AHP) hierarchy (Saaty 1990) that decomposes high-level omnichannel capability domains into individual capabilities at a lower level and further into organizational practices at the lowest level. By formally describing proven practices of managing omnichannel services, this hierarchy supports capability management, particularly in the knowledge acquisition phase. The availability of this hierarchy is a precondition for the specification of factor weights and the assessment of projects for developing omnichannel capabilities by means of the AHP method (Vaidya and

\footnotetext{
${ }^{1}$ In this article we focus on B2C industries and use the terms consumer and customer interchangeably.
} 
Kumar 2006). We followed Peffers et al. (2007) guidelines for the design of the design science research (DSR) procedure. We conducted a focus group in order to identify solution requirements and used expert interviews and case studies for hierarchy development. The resulting AHP hierarchy was evaluated by discussing the results of a demonstration case at a global car manufacturer.

With our results, we contribute to the literature on omnichannel management in various ways. First, to our knowledge, this is the first DSR effort with the goal to provide a theory for design and action. Moreover, by using a capability conceptualization that is grounded in the resource-based literature (Amit and Schoemaker 1993; Grant 1991) and by introducing a structure of service domains, capabilities, and practices we provide a model that is applicable for managing omnichannel capabilities.

\section{Theoretical background}

Omnichannel management definitions in the academic literature comprise an omnichannel service perspective (Sect. 2.1) and an omnichannel capability perspective (Sect. 2.2) (Verhoef et al. 2015; Beck and Rygl 2015; Picot-Coupey et al. 2016).

\subsection{Omnichannel services}

The omnichannel service perspective characterizes the customer-oriented outcome of omnichannel management and describes the characteristics of omnichannel services, i.e. value-creating customer interactions (Vargo et al. 2008). For example, Verhoef et al. (2015, p. 3) define omnichannel management as "the synergetic management of the numerous available channels and customer touchpoints, in such a way that the customer experience across channels and the performance over channels is optimized". Omnichannel services thus provide a high customer experience that relates to a broad channel scope and to a broad scope of customerand provider-triggered channel interactions (Beck and Rygl 2015; Hübner et al. 2016a). In contrast to services in more preliminary multi-channel or cross-channel management approaches, omnichannel services cover not only a subset, but all available customer channels (Hoogveld and Koster 2016).

Omnichannel services are not limited to the buying phase. Instead, they cover all product- or service-specific customer interactions in the customer lifecycle. Stressing this point, Picot-Coupey et al. (2016) define omnichannel management as "a strategy that manages channels as intermingled touch points to allow consumers to live a seamless experience within a brand ecosystem" (Picot-Coupey et al. 2016, p. 342). In summary, based on Verhoef et al. (2015), Picot-Coupey et al. (2016) and Beck and Rygl (2015) we define omnichannel services as customer interactions in $\mathrm{B} 2 \mathrm{C}$ markets that create value by relating to the complete scope of channels and customer lifecycle phases. 


\subsection{Managing omnichannel capabilities}

Verhoef et al. (2015, p. 3) in their omnichannel management definition explicitly refer to a "synergetic management" of channels and state that an integrated channel management with cross-channel objectives such as overall customer experience and total sales over all channels is the main differentiator to a multi-channel management with siloed channel management structures. In addition to capabilities that address management structures and roles, data- and IT-oriented capabilities, such as the integration of customer and service or product data, are regularly considered as constitutive elements of omnichannel management (Beck and Rygl 2015). In line with the resource-based definition of organizational capabilities (Amit and Schoemaker 1993; Grant 1991), we define omnichannel capabilities as organizational practices that address key organizational objectives in the provisioning of omnichannel services.

The development of organizational capability is an act of organizational learning that consists of knowledge acquisition, knowledge adaptation, knowledge application (i.e., communication and transfer), and knowledge appropriation (i.e., use of transferred knowledge) (Szulanski and Jensen 2006; Rauffet et al. 2016). Organizational capability management supports organizational learning in all four phases (Rauffet et al. 2012, 2016). Knowledge acquisition is supported by capability models that compile and structure capabilities in specific domains. Such capability models have equally been developed by academic researchers (e.g. Lichtenthaler and Lichtenthaler 2009; Ashurst et al. 2008; Hosseini et al. 2017) and, in the form of 'good practice frameworks', by practitioner initiatives (e.g. TSO 2012; ITGI 2009; ISO/IEC 2010).

An analysis of peer-reviewed articles on capability models for omnichannel services, which we retrieved by searching for the term "omnichannel" in various digital libraries following vom Brocke et al. (2009) guidelines, yielded two research gaps (see Appendix 1 for an overview of the reviewed articles). First, the reviewed literature broadly exhibits a low level of formalization with regard to using welldefined constructs and structuring the omnichannel capabilities in a model. The reviewed articles refer to different constructs related to omnichannel capabilities, such as important areas (Piotrowicz and Cuthbertson 2014), organizational factors (Hoogveld and Koster 2016), and competencies (Hübner et al. 2016b), and provide little theoretical groundings for their constructs. Only two articles define a structure of omnichannel capabilities. Hoogveld and Koster (2016) provide an aggregate perspective and distinguish four domains of organizational factors (omnichannel strategy, people, organizational structure, information systems, and agile processes) without further specifying individual capabilities or practices in these domains. Picot-Coupey et al. (2016) adopt a two-level capability perspective: They describe strategy-related (organizational, cultural, managerial, marketing and financial) and development-related (retailing mix, IS, CRM) challenges and describe practices to address these challenges. Their model, however, is specific to the transitional challenges of e-tailers.

Second, with regard to research methods, prior research used case studies (Hansen and Sia 2015; Brynjolfsson et al. 2013; Picot-Coupey et al. 2016), 
interviews and focus groups (Piotrowicz and Cuthbertson 2014; Parise et al. 2016; Peltola et al. 2015), literature analysis (Hoogveld and Koster 2016; Melero et al. 2016; Härtfelder and Winkelmann 2016), and a survey (Luo et al. 2016). The supporting of organizational capability management for omnichannel services, however, requires prescriptive theories for design and action and the application of DSR approaches (Gregor 2006).

\section{Research method}

In order to address the industry demand for omnichannel management instruments (Econsultancy 2013; Frost \& Sullivan 2015; Lauchlan 2017b; Ovum 2017) and the research gaps in the omnichannel management literature (see Sect. 2.2), it is our research objective to develop an AHP hierarchy that describes and structures omnichannel capabilities. Such an AHP hierarchy directly supports the knowledge acquisition phase in omnichannel capability management and, by enabling the implementation of an AHP method, it indirectly supports further capability management phases (Rauffet et al. 2012, 2016). In the following, we motivate the choice of a DSR approach for AHP hierarchy development and describe the DSR procedure.

\subsection{AHP hierarchy as DSR artifact}

Owing to the AHP method's proven applicability to support organizational decision problems (Vaidya and Kumar 2006; Rebs et al. 2018), ${ }^{2}$ we chose to develop an AHP hierarchy that aggregates assessment factors of projects for omnichannel capability development. An AHP hierarchy thoroughly arranges the factors that are relevant for a decision in a hierarchic structure descending from an overall goal for decisionmaking at the top to decision factors and subfactors at the successive levels and the decision alternatives at the lowest level (Saaty 1990). Such a hierarchy partitions a decision into a manageable amount of relative comparisons of factors within the same cluster (Saaty 1990, p. 10). In an AHP hierarchy, all decision factors must not be influenced by factors at the same or at superordinate tiers; similarly, the decision alternatives must be independent of the decision factors and of each other (Saaty 2005). The construction of a hierarchy has a crucial importance in the AHP process because incomprehensive hierarchies lead to an overemphasis of selected factors and including irrelevant factors leads to factor under-emphasis, both resulting in biased decisions (Saaty 1990).

The DSR methodology has commonly been applied by prior research to develop organizational decision instruments (Welter et al. 2013; Cleven et al. 2014; Afflerbach et al. 2016; Lehnert et al. 2016). We consider the construction of an AHP hierarchy a DSR task (and not a routine design task) for two reasons (Hevner et al. 2004). First, DSR produces knowledge that is relevant to a class of problems

\footnotetext{
${ }^{2}$ See (Saaty 1990) for an introduction to the AHP method and illustrative examples. Vaidya and Kumar (2006) provide an overview of AHP applications.
} 
whereas routine design focuses on a particular, situated problem. As discussed in Sect. 1, firms in different B2C markets face similar challenges with regard to developing omnichannel capabilities. Hence, an omnichannel capability model represents a "meta-design" (Walls et al. 1992, p. 42) that is dedicated to broadly supporting capability management at omnichannel service providers. Second, DSR applies to the development of novel solutions or to the addressing of new problems (Gregor and Hevner 2013). Only if the problem is well understood and existing artifacts can be applied to address the problem, routine design is sufficient since, in this case, little research opportunity exists. In the case of omnichannel capabilities, however, no "best practice" frameworks exist that could readily be applied in routine design (see Sect. 2.2).

\subsection{DSR procedure}

Regarding the research procedure, we adopted a problem-centered approach as described by Peffers et al. (2007). We discuss the individual research activities below.

Activity 1: Problem identification and motivation In order to define the specific research problem and justify the value of a solution, we consulted practitioner and academic literature. Several reports in practitioner literature show that today's omnichannel customers demand a high user experience and a seamless flow of information between service channels and that, despite high customer expectations, the large majority of service providers is unable to provide such a high degree of channel integration and customer experience (Accenture 2013; Consumers 2016). In the academic literature, several authors report that omnichannel services require the development of novel organizational capabilities (Beck and Rygl 2015; PicotCoupey et al. 2016; Verhoef et al. 2015). In this transformation, however, providers of B2C services face considerable challenges (Melero et al. 2016; Härtfelder and Winkelmann 2016; Picot-Coupey et al. 2016). Consequently, they are in urgent need to improve omnichannel capabilities and require assisting management instruments (Econsultancy 2013; Frost \& Sullivan 2015; Ovum 2017).

Activity 2: Define the objectives for a solution Even though insufficient omnichannel service offerings are caused by poorly developed omnichannel capabilities (Hoogveld and Koster 2016), our analysis of the literature of omnichannel capabilities shows that there is a clear lack of design-oriented research to support the management of omnichannel capabilities (see Sect. 2.2). In order to address this research gap, the objective of our research is the development of an omnichannel capability model in the form of an AHP hierarchy. The solution objective is to support capability management in the knowledge acquisition phase by assisting the formulation of 'problem and solution statements' (March and Smith 1995, p. 256) that describe required omnichannel capabilities of a B2C service provider. In order to generate model requirements, we conducted a focus group and identified two requirements that relate to the model scope and the type of facilitated service innovation (see Sect. 4.1).

Activity 3: Design and development The available research on omnichannel capabilities lacks well-defined models that describe capability constructs and 
structures (see Sect. 2.2) and insufficiently satisfies the solution requirements (see Sect. 4.2.1). For these reasons, we decided to develop an AHP hierarchy by means of a problem-based approach (Peffers et al. 2007) and to consult Alter $(2008,2011)$ service systems framework as kernel theory. We conducted interviews with six subject-matter experts in order to specify omnichannel capabilities (see Sect. 4.2.2). In a final step, we conducted a multiple case study analysis in order to assemble practices that can be adopted to successfully implement a capability (see Sect. 4.2.3).

Activity 4: Demonstration We demonstrate the use of the capability model at a global automobile manufacturer (see Sect. 5). The demonstration case includes interviews with six executive managers to assess hierarchy completeness, to collect factor comparisons and to generate factor weightings as well as a workshop to present and collect feedback on the results.

Activity 5: Evaluation In order to observe and measure how well the developed capability model supports the solution objective, i.e. the specification of required omnichannel capabilities, we in a first step assessed the developed model against the model requirements. In a second step we used the results of the demonstration case to evaluate the model with respect to the following evaluation criteria: level of detail, fidelity with real-world phenomena, internal consistency, robustness, effectivity and efficiency, and impact on the artifact environment (March and Smith 1995; Sonnenberg and vom Brocke 2012).

\section{Model synthesis}

\subsection{Determination of solution objectives}

In order to validate whether the AHP hierarchy would contribute to solving an important business problem and in order to collect solution objectives, we conducted an exploratory focus group workshop (Tremblay et al. 2010). To receive a sufficient breadth of input and guarantee a high level of participant involvement, we invited 18 subject-matter experts, who are potential users of the AHP hierarchy and represent diverse positions (e.g. CIO, service manager, innovation manager), industries (e.g. utilities, sports, digital services, consumer goods), and institutions (e.g. B2C company, consultancy, company association).

Within the workshop, the participants were asked to describe the challenges of B2C organizations that an AHP hierarchy of omnichannel capabilities should address. We protocolled the focus group discussion and used conventional content analysis (Hsieh and Shannon 2005) in order to identify solution objectives for the AHP hierarchy that result from the discussed challenges and capability implications.

The analysis yielded two solution objectives for the AHP hierarchy. First, regarding capability scope, the model should cover outside-in, inside-out, and spanning capabilities (Requirement 1) The participants identified challenges that relate to and require all three capability types that are defined by Wade and Hulland (2004). For instance, the challenge that services must be assessed "from a customer point of view" (CIO, Energy) relates to outside-in capabilities to identify customer 
requirements and create durable customer relationships. The challenge of "customer identification" (Data Management Lead, Consumer Goods) relates to inside-out capabilities to implement reactions to external requirements and opportunities. The challenge of the "measurement and modeling of cross-channel customer journeys" (Consultant, Retail) relates to spanning capabilities that involve internal as well as external analysis.

Second, modeled capabilities should facilitate two types of service innovation: customer-data-driven and channel-technology-driven innovation (Requirement 2) As a superordinate class of challenges, the participants repeatedly mentioned the design of data-driven services that provide personalized value propositions. The implementation of such personalized services, according to the participant discussion, includes subordinate challenges such as the implementation of service usage analytics, customer identification, real-time data usage, and data-driven management. The second class of challenges mentioned by the participants relates to channel-technology driven innovation. Providing a unified customer experience across all channels, according to the participants, involves subordinate challenges such as the provision of integrated customer-facing systems, the coordination of channel-specific organizational silos, and the tracking of cross-channel customer activities. Table 1 shows exemplary quotes that describe challenges, which relate to the three classes of capabilities (requirement 1) and two types of service innovation (requirement 2).

\subsection{Hierarchy development}

In the following, we describe the hierarchy development procedure and the resulting AHP hierarchy (see Table 5 for a hierarchy overview). We motivate our choice of kernel theory. Further, we present the results of a cross-interview analysis and multiple case studies that we conducted in order to motivate and evaluate design choices in our construction process (Sonnenberg and vom Brocke 2012).

\subsubsection{Kernel theory}

An assessment of the prior literature on omnichannel capabilities discussed in Sect. 2.2 with regard to the focus group requirements yielded that no capability model fully covers outside-in, inside-out, and spanning capabilities for data-driven and channel-technology-driven service innovations (see Appendix 1). Owing to the incomplete requirements coverage and to the lack of formalized capability models (see Sect. 2.2), we consulted a general-purpose taxonomy in order to structure capabilities for omnichannel services, the service system framework (Alter 2008, 2011). Due to the framework's scope to cover "all operational systems that provide services" (Alter 2011, p. 7) it qualifies as a general structure for omnichannel capabilities. The service system framework suggests a decomposition of omnichannel capabilities into eight domains at tier 1 of the AHP hierarchy. The customer domain (Tier 1 ID: 1) covers the interaction with the direct beneficiaries of omnichannel services. The strategy domain (Tier 1 ID: 2) describes the guiding rationale and the strategic choices in the design and delivery of omnichannel 
Table 1 Focus group results-solution requirements and exemplary challenges

\begin{tabular}{|c|c|c|}
\hline RQ1\RQ2 & Customer-data-driven innovation & Channel-technology-driven innovation \\
\hline $\begin{array}{l}\text { Outside-in } \\
\text { capabilities }\end{array}$ & $\begin{array}{l}\text { "New data-driven services" (vice } \\
\text { president data science, online } \\
\text { services) } \\
\text { "Targeted customer approach" (Head } \\
\text { Innovation Center, energy) } \\
\text { "Services must be assessed from a } \\
\text { customer point of view" (CIO, } \\
\text { energy) }\end{array}$ & $\begin{array}{l}\text { "Unified user experience (multichannel)" } \\
\text { (Vice President Data Science, Online } \\
\text { Services) } \\
\text { "360-degree customer view across all } \\
\text { touchpoints" (Head of Digital Strategy and } \\
\text { Business Development, Travel) } \\
\text { "Match consumer needs with brand services } \\
\text { and channels" (data management lead, } \\
\text { consumer goods) }\end{array}$ \\
\hline $\begin{array}{l}\text { Inside-out } \\
\text { capabilities }\end{array}$ & $\begin{array}{l}\text { "Creation of customer profiles" } \\
\text { (principal consultant, data quality } \\
\text { consulting) } \\
\text { "Customer/entity identification" (data } \\
\text { management lead, consumer goods) } \\
\text { "Real-time data usage" (head } \\
\text { collaborative supply chains, company } \\
\text { association) }\end{array}$ & $\begin{array}{l}\text { "Integrated systems for online and offline" } \\
\text { (head of digital strategy and business } \\
\text { development, travel) } \\
\text { "Integration of customer-facing systems } \\
\text { (apps, websites, social media) into one } \\
\text { platform" (Product Information } \\
\text { Management, Consumer Goods) } \\
\text { "Use social networks for personal interaction } \\
\text { with customers" (CIO, energy) }\end{array}$ \\
\hline $\begin{array}{l}\text { Spanning } \\
\text { capabilities }\end{array}$ & $\begin{array}{l}\text { "We must know how to use customer } \\
\text { information to innovate our services" } \\
\text { (CIO, energy) } \\
\text { "Manage transformation towards } \\
\text { customer-centric interactions" (CIO, } \\
\text { medical technology) } \\
\text { "Operationalization of data insights" } \\
\text { (consultant, retail) }\end{array}$ & $\begin{array}{l}\text { "Channel coordination" (head innovation } \\
\text { center, energy) } \\
\text { "How to overcome silo mentality and work in } \\
\text { a more integrated manner across digital } \\
\text { landscape" (product information } \\
\text { management, consumer goods) } \\
\text { "Measurement and modeling of cross- } \\
\text { channel customer journeys" (consultant, } \\
\text { retail) }\end{array}$ \\
\hline
\end{tabular}

$R Q$ requirement

\# Participants: 17; Participant industries (selected): energy, chemicals, consumer goods, sports, online services, software, travel; participant roles (selected): chief information officer, head digital innovation, head data management, head data science; head of digital strategy and business development

services. The processes and activities domain (Tier 1 ID: 3 ) includes the formal and informal activities that are conducted during omnichannel service design and provisioning. The IT and infrastructure domain (Tier 1 ID: 4) covers all relevant tools, specialized techniques, and shared resources. We did not keep Alter (2008) distinction of technologies and infrastructures for reasons of parsimony. The participants domain (Tier 1 ID: 5) describes all stakeholders who perform nonautomated tasks in the provisioning of omnichannel services. The services domain (Tier 1 ID: 6) describes how omnichannel services generate value for customers and service providers. The information domain (Tier 1 ID: 7) defines the flow and usage of data that are consumed and generated by omnichannel services. The environment domain (Tier 1 ID: 8) characterizes the market environment, in which omnichannel services are provided, and includes competitive, regulatory, and technical aspects. 


\subsubsection{Omnichannel capabilities}

In order to specify omnichannel capabilities, we conducted interviews with six subject-matter experts (average duration: $70 \mathrm{~min}$ ). We adopted a theoretical sampling approach (Strauss and Corbin 1998, p. 73), inviting experts that represent different B2C institutions, industries (e.g. retail, education, insurance) and roles (e.g. Head Direct Sales, Head Marketing, CIO), and reached theoretical saturation after coding six interviews. Theoretical saturation refers to the "point in category development at which no new properties, dimensions, or relationships emerge during analysis" (Strauss and Corbin 1998, p. 143).

At the beginning of each interview, we provided our definitions of omnichannel services and omnichannel capabilities as well as a description of the service system framework. We then asked the interviewees to describe key organizational objectives (i.e. capability goals) that represent preconditions for providing omnichannel services in each domain of the service system framework (Alter 2008). We followed a cross-interview analysis procedure (Patton 2014) and compared the capabilities mentioned in the different interviews in order to identify common capabilities and potential structural differences. We only dropped one technology-oriented capability, industrialized backend systems, that was mentioned by one interviewee owing to its low specificity to the case of omnichannel services. As shown in Table 2, there was a high consistency among the interviewees, which all covered above $70 \%$ of the considered capabilities. We identified 17 capability goals in the cross-interview analysis that form Tier 2 of the AHP hierarchy.

Each service system domain is superordinate to two to three capabilities. For instance, the customer domain (Tier 1 ID: 1) encompasses two capabilities. Consumer orientation (Tier 2 ID: 1A) has the objective to clearly define, operationalize and monitor the value proposition of an omnichannel service. The head of business engineering at a bank (Expert A) criticized that the frontend organization at his company currently is exclusively focused on new sales, even though measuring customer experience is becoming more and more important in an omnichannel environment. Similarly, a manager of business development at a retail company (Expert F) stated that generating and acting upon consumer feedback is a crucial capability. Consumer agility (Tier 2 ID: 1B) is associated with the goal to readily sense consumer demands and to respond to these demands with new value propositions in a timely fashion. The head of direct sales at a health insurance company (Expert E) highly valued the capability to prototype omnichannel service concepts because it allows testing and immediate learning in cooperation with customers. Similarly, the head of business architecture at a property insurance (Expert D) emphasized that the capability to pilot omnichannel services without the necessity for technological backend integration is an important cornerstone in channel development.

\subsubsection{Omnichannel practices}

In order to assemble practices that can be adopted to successfully achieve Tier 2's capability goals, we conducted a multiple case study analysis (Pare 2004; 
Table 2 Results of the cross-interview analysis

\begin{tabular}{|c|c|c|c|c|c|c|c|c|c|}
\hline \multirow{2}{*}{$\begin{array}{l}\text { T1 } \\
\text { ID }\end{array}$} & \multirow{2}{*}{$\begin{array}{l}\mathrm{T} 2 \\
\mathrm{ID}\end{array}$} & \multirow[t]{2}{*}{ Capability } & \multirow[t]{2}{*}{ Capability goal } & \multicolumn{6}{|c|}{ Interviewees } \\
\hline & & & & A & B & $\mathrm{C}$ & D & E & $\mathrm{F}$ \\
\hline \multirow[t]{2}{*}{1} & $1 \mathrm{~A}$ & $\begin{array}{l}\text { Consumer } \\
\text { orientation }\end{array}$ & $\begin{array}{l}\text { Customer value propositions of } \\
\text { omnichannel services are } \\
\text { operationalized and monitored }\end{array}$ & $\mathrm{x}$ & $\mathrm{x}$ & $\mathrm{x}$ & $\mathrm{x}$ & $\mathrm{x}$ & $\mathrm{x}$ \\
\hline & 1B & Consumer agility & $\begin{array}{l}\text { Omnichannel services are managed in an } \\
\text { agile fashion }\end{array}$ & $\mathrm{x}$ & $\mathrm{x}$ & $\mathrm{x}$ & $\mathrm{x}$ & $\mathrm{x}$ & $\mathrm{x}$ \\
\hline \multirow[t]{2}{*}{2} & $2 \mathrm{~A}$ & $\begin{array}{l}\text { Omnichannel } \\
\text { strategy }\end{array}$ & $\begin{array}{l}\text { Strategic objectives of omnichannel } \\
\text { management are aligned with } \\
\text { company's business strategy and } \\
\text { supported by top management }\end{array}$ & $\mathrm{x}$ & $\mathrm{x}$ & $\mathrm{x}$ & $\mathrm{x}$ & $\mathrm{x}$ & $\mathrm{x}$ \\
\hline & $2 \mathrm{~B}$ & $\begin{array}{l}\text { Initiative } \\
\quad \text { coordination }\end{array}$ & $\begin{array}{l}\text { Omnichannel management in your } \\
\text { organization is well planned and } \\
\text { coordinated across the entire company }\end{array}$ & $\mathrm{x}$ & $\mathrm{x}$ & $\mathrm{x}$ & $\mathrm{x}$ & $\mathrm{x}$ & $\mathrm{x}$ \\
\hline \multirow[t]{2}{*}{3} & $3 \mathrm{~A}$ & $\begin{array}{l}\text { Process } \\
\quad \text { reconfiguration }\end{array}$ & $\begin{array}{l}\text { Business processes are reconfigured in } \\
\text { order to exploit the business potential } \\
\text { of omnichannel services }\end{array}$ & $\mathrm{x}$ & $\mathrm{x}$ & $\mathrm{x}$ & $\mathrm{x}$ & $\mathrm{x}$ & $\mathrm{x}$ \\
\hline & $3 \mathrm{~B}$ & Privacy & $\begin{array}{l}\text { Data transparency and privacy is fully } \\
\text { enabled }\end{array}$ & $\mathrm{x}$ & $\mathrm{x}$ & $\mathrm{x}$ & $\mathrm{x}$ & $\mathrm{x}$ & $\mathrm{x}$ \\
\hline \multirow[t]{2}{*}{4} & $4 \mathrm{~A}$ & $\begin{array}{l}\text { Channel } \\
\text { integration }\end{array}$ & $\begin{array}{l}\text { An integrated customer experience is } \\
\text { provided through a coordination and } \\
\text { flexible design of customer-centric } \\
\text { systems and offline channels }\end{array}$ & $\mathrm{x}$ & $\mathrm{x}$ & $\mathrm{x}$ & $\mathrm{x}$ & $\mathrm{x}$ & \\
\hline & 4B & $\begin{array}{r}\text { Analytical } \\
\text { systems }\end{array}$ & $\begin{array}{l}\text { A customer analytics infrastructure fully } \\
\text { enables the exploitation of customer } \\
\text { analytics scenarios }\end{array}$ & $\mathrm{x}$ & $\mathrm{x}$ & $\mathrm{x}$ & $\mathrm{x}$ & $\mathrm{x}$ & \\
\hline \multirow[t]{3}{*}{5} & $5 \mathrm{~A}$ & $\begin{array}{l}\text { Roles and } \\
\quad \text { responsibilities }\end{array}$ & $\begin{array}{l}\text { Roles, tasks, and responsibilities for } \\
\text { managing omnichannel services are } \\
\text { clearly defined, documented, and } \\
\text { communicated }\end{array}$ & $\mathrm{x}$ & $\mathrm{x}$ & $\mathrm{x}$ & $\mathrm{x}$ & $\mathrm{x}$ & $\mathrm{x}$ \\
\hline & $5 \mathrm{~B}$ & Collaboration & $\begin{array}{l}\text { Cross-functional and cross-disciplinary } \\
\text { collaboration is fully enabled }\end{array}$ & $\mathrm{x}$ & $\mathrm{x}$ & $\mathrm{x}$ & $\mathrm{x}$ & $\mathrm{x}$ & $\mathrm{x}$ \\
\hline & $5 \mathrm{C}$ & $\begin{array}{l}\text { Competencies } \\
\text { management }\end{array}$ & $\begin{array}{l}\text { Knowledge and competencies for } \\
\text { managing omnichannel services and } \\
\text { thereby exploiting customer } \\
\text { information in decision making are } \\
\text { fully acquired and developed }\end{array}$ & $\mathrm{x}$ & $\mathrm{x}$ & $\mathrm{x}$ & $\mathrm{x}$ & $\mathrm{x}$ & $\mathrm{x}$ \\
\hline \multirow[t]{2}{*}{6} & $6 \mathrm{~A}$ & Personalization & $\begin{array}{l}\text { Omnichannel services are tailored to } \\
\text { personal context based on customer } \\
\text { information }\end{array}$ & $\mathrm{x}$ & $\mathrm{x}$ & $\mathrm{x}$ & $\mathrm{x}$ & & $\mathrm{x}$ \\
\hline & $6 \mathrm{~B}$ & $\begin{array}{l}\text { Business } \\
\text { orientation }\end{array}$ & $\begin{array}{l}\text { The business impact of omnichannel } \\
\text { services is operationalized and } \\
\text { monitored with suitable metrics }\end{array}$ & $\mathrm{x}$ & $\mathrm{x}$ & $\mathrm{x}$ & $\mathrm{x}$ & $\mathrm{x}$ & $\mathrm{x}$ \\
\hline \multirow[t]{2}{*}{7} & $7 \mathrm{~A}$ & Data exploitation & $\begin{array}{l}\text { The business potential of customer data is } \\
\text { continuously evaluated and acted upon }\end{array}$ & $\mathrm{x}$ & $\mathrm{x}$ & $\mathrm{x}$ & $\mathrm{x}$ & $\mathrm{x}$ & $\mathrm{x}$ \\
\hline & $7 \mathrm{~B}$ & $\begin{array}{l}\text { Data } \\
\text { management }\end{array}$ & $\begin{array}{l}\text { Methods and architectures for managing } \\
\text { customer data fully enable data } \\
\text { exploitation }\end{array}$ & $\mathrm{x}$ & $\mathrm{x}$ & $\mathrm{x}$ & $\mathrm{x}$ & & \\
\hline
\end{tabular}


Table 2 continued

\begin{tabular}{|c|c|c|c|c|c|c|c|c|c|}
\hline \multirow{2}{*}{$\begin{array}{l}\text { T1 } \\
\text { ID }\end{array}$} & \multirow{2}{*}{$\begin{array}{l}\mathrm{T} 2 \\
\mathrm{ID}\end{array}$} & \multirow[t]{2}{*}{ Capability } & \multirow[t]{2}{*}{ Capability goal } & \multicolumn{6}{|c|}{ Interviewees } \\
\hline & & & & A & B & $\mathrm{C}$ & $\mathrm{D}$ & $\mathrm{E}$ & $\mathrm{F}$ \\
\hline \multirow[t]{2}{*}{8} & $8 \mathrm{~A}$ & $\begin{array}{c}\text { Ecosystem } \\
\text { position }\end{array}$ & $\begin{array}{l}\text { Sustainable customer access in the } \\
\text { digitized consumer market is secured } \\
\text { and continually improved by engaging } \\
\text { in strategic partnerships }\end{array}$ & $\mathrm{x}$ & $\mathrm{x}$ & $\mathrm{x}$ & $\mathrm{x}$ & $\mathrm{x}$ & \\
\hline & $8 \mathrm{~B}$ & $\begin{array}{l}\text { Market } \\
\text { orientation }\end{array}$ & $\begin{array}{l}\text { The management of omnichannel } \\
\text { services incorporates a thorough } \\
\text { analysis of market and technology } \\
\text { developments }\end{array}$ & $\mathrm{x}$ & $\mathrm{x}$ & $\mathrm{x}$ & $\mathrm{x}$ & $\mathrm{x}$ & \\
\hline
\end{tabular}

T1 ID Tier 1 ID; T2 ID Tier 2 ID; $x$ occurrence; 1 customer domain, 2 strategy domain, 3 processes domain, 4 IT and infrastructure domain, 5 participants domain, 6 services domain, 7 information domain, 8 environment domain, $A$ Head Business Engineering (Banking); $B$ CIO (education); $C$ Head Marketing (Education); $D$ Head Business Architecture (Property Insurance); $E$ Head Direct Sales (Health Insurance); $F$ Manager Business Development (Retail)

Eisenhardt 1989; Yin 2013). In case selection, we followed a theoretical sampling strategy with the aim to replicate findings across multiple cases (Yin 2013, p. 47). We focused on large for-profit organizations in B2C markets since these contingencies may influence omnichannel adoption (Lundqvist et al. 2017; Wirtz and Langer 2016). Further, we chose organizations from retail, consumer goods, and consumer services markets and different regional foci (national versus global) to improve the generalizability of our findings (cp. Eisenhardt 1989). We consulted customer experience surveys and digital service benchmarks and only considered companies with a high level of documented omnichannel service excellence because we are solely interested in practices that successfully support omnichannel services. We stopped after the analysis of four case studies since we did not extract significant new insights suggesting a point of theoretical saturation (Strauss and Corbin 1998, p. 143). An overview of cases and data sources is provided in Table 3.

We conducted interviews with two subject-matter experts (representing omnichannel management roles such as head of digital services, head of IT strategy, head of customer intelligence, and head of data management) at each case site. In the interviews (average duration: $90 \mathrm{~min}$ ), we included for each capability goal in Tier 2 open-ended questions about the adoption of associated practices. The results were protocolled and validated by the interviewees. For triangulation purposes, we further consulted internal case material provided by the companies such as presentations, strategy documents, and annual reports. The case data was analyzed regarding whether there is strong evidence (i.e. fully positive performance impacts), partial evidence (i.e. initial positive performance impacts), or no evidence (i.e. no positive impacts) of a practice. Results are shown in Table 4. We identified an overall number of 46 practices, for which we found full or partial evidence. These practices form the tier 3 of our AHP hierarchy. There was a strong consistency among the cases, as all cases provided at least partial evidence for $87 \%$ of the collected practices. 
Table 3 Cases and data sources

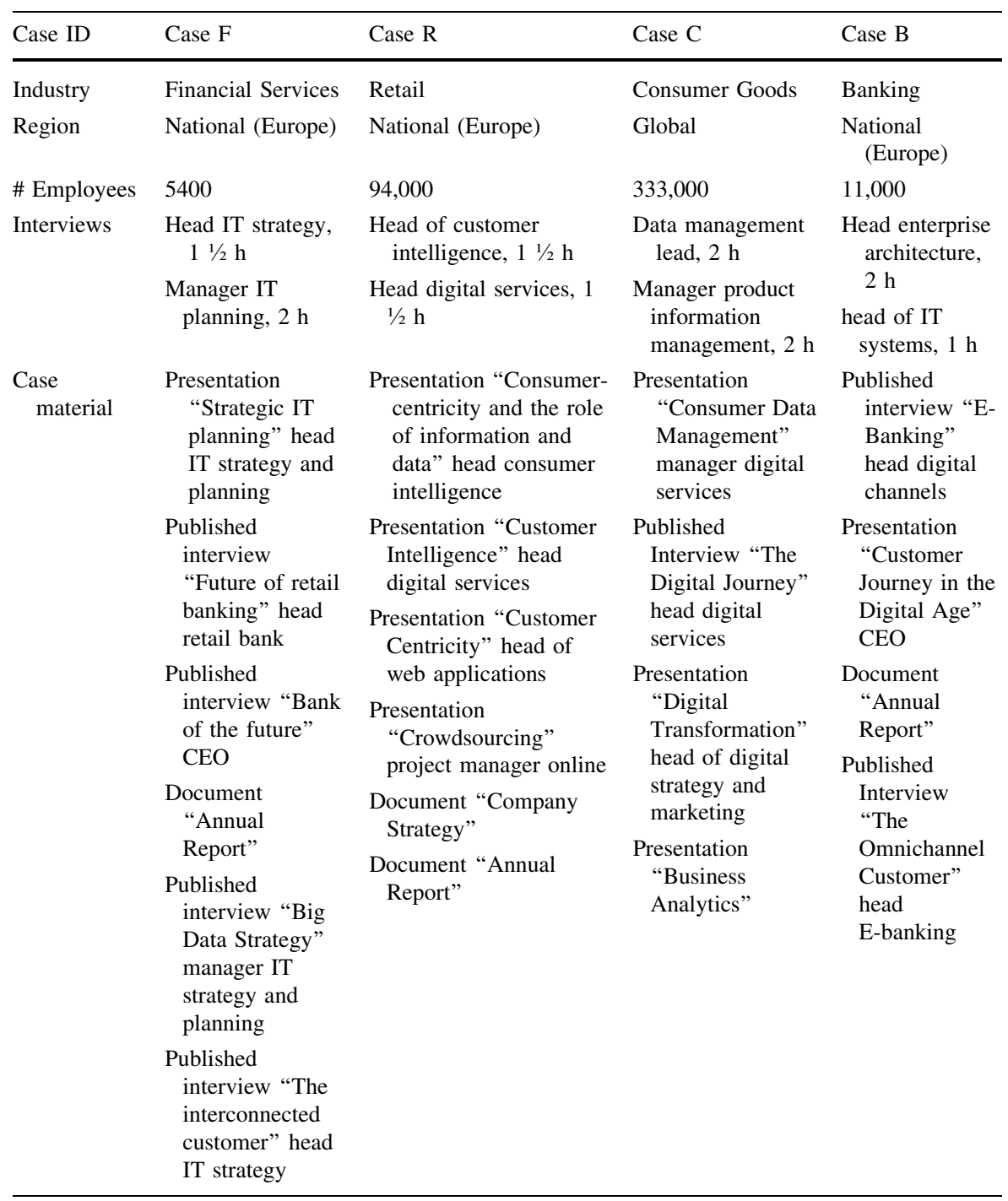

Each capability is superordinate to two to four practices. The capability consumer agility (Tier 2 ID: 1B), for example, is superordinate to three practices. The practice consumer-centric design (Tier 3 ID: 1B1) includes methods such as contextual inquiry, design thinking, prototyping, and customer focus groups. In the case of the financial service provider (Case F), we found multiple pieces of evidence for positive and mature experiences with customer focus groups to test omnichannel concepts in early project phases. Due to this maturity, we coded the case evidence as "strong". In the bank case (Case B), a design thinking project was conducted by external staff to explore a blended channel scenario. The head of enterprise 
Table 4 Results of multiple case study analysis

\begin{tabular}{llllll}
\hline T3 & Practice: description & R & C & F & B \\
ID & & & &
\end{tabular}

1A1 Consumer surveys: Conduct qualitative or quantitative consumer surveys to $+\quad+\quad \mathrm{o}+$ identify consumer satisfaction and requirements

1A2 Consumer intelligence: Conduct analysis of usage data to identify consumer $0+\mathrm{o}_{-}$ satisfaction and requirements

1B1 Consumer-centric design methods: Apply consumer-centric design methods $++\quad+\quad \mathrm{o}$ such as contextual inquiry, design thinking, prototyping, and consumer innovation labs

1B2 Agile service management methods: Apply methods to enable flexibility and $\mathrm{o}+{ }_{+}+$ speed in omnichannel service development and operations (e.g. agile software development)

1B3 Innovation management methods: Implement innovation stimuli (such as employee innovation rewards), consumer innovation funnel, and crowdsourcing mechanisms

2A1 Omnichannel vision and objectives: Create a general vision at top management level as well as within the entire company of how the evolution towards omnichannel affects the market and your company

2A2 Channel strategy: Create a shared vision of how channels should be designed $+\quad \mathrm{o}++$ and blended to support future consumer interaction

2A3 Service strategy: Create a shared vision of how the transformation towards $\begin{array}{lllll}\text { o } & \text { o } & +\end{array}$ omnichannel affects the service portfolio

2A4 Consumer segmentation: Implement a segmentation approach which takes +++ o into account the evolving use of digital technologies, channels and digital services

2B1 Digital program: Design and manage investment plans and resource allocation for omnichannel management which reflect omnichannel vision and objectives

2B2 Portfolio management: Manage cross-functional portfolio of omnichannel initiatives

3A1 Frontend reconfiguration: Enable customer co-creation throughout the frontend processes (e.g. self-service processes or closed-loop marketing)

3A2 Frontend-backend-integration: Enable demand-adaptive and channelagnostic backend processes (e.g. in logistics or pricing) and dynamic partnership configurations

3B1 Security certification: Externally certify consumer data management practices

3B2 Self-service privacy: Provide transparency on data, data use, and interactions as well as configuration options through portal and/or app

3B3 Privacy communication: Proactively inform consumers about data use (incl. $+\mathrm{o}_{+}^{+}$ consumer opt-ins)

4A1 Online channel integration: Integrate digital consumer touchpoints and support channel switching, single sign-on, and universal data access

4A2 Online offline integration: Integrate online and offline channels, provide blend of offline and online content

4A3 Modular channel architecture: Implement modular frontend architecture to enable flexible channel design and consistent communication

4B1 Consumer analytics architecture: Provide and integrate analytical information systems, such as web analytics systems and transactional analytics systems 
Table 4 continued

\begin{tabular}{llllll}
\hline T3 & Practice: description & R & C & F & B \\
ID & & & &
\end{tabular}

4B2 Big data architecture: Install data management systems which exploit $+\quad+\quad$ o technologies to enable high-velocity decision making and high volume and variety data processing

4B3 Data access and analysis policies: Implement standards and policies for easily $\quad-\quad+\quad o \quad o$ accessing and analyzing consumer data

5A1 Roles: Define key roles in omnichannel management and remove vertical, $+\quad+\quad+\quad$ o channel-oriented structures

5A2 Competence centers: Install dedicated units to gather key omnichannel capabilities (e.g. web tech unit, consumer analytics unit, prototyping unit)

5A3 Gremiums: Install governance mechanisms which involve all relevant stakeholders in omnichannel management (including marketing, sales, IT, product management, category management)

5B1 Cross-functional incentives: Create cross-functional project teams and collaboration incentives (e.g. customer-centric performance indicators in employee performance management)

5B2 Interdisciplinary project management: Install interdisciplinary project managers and expert teams

5B3 Informal mechanisms: Communicate and set examples for culture of collaboration such as mixed office designs

5C1 Capability planning: Carry out omnichannel capability profiling and planning

5C2 Education and training: Launch omnichannel education programs (such as analytics training, mobile technology training etc.) and support exploitation of internal knowhow

5C3 Expert acquisition: Hire subject-matter experts from outside (e.g. data scientists) and establish strategic cooperation with partner firms to get access to external competencies in omnichannel management

6A1 Predictive analytics: Use analytics to predict a consumer's preferences based +++++ on its current and past behavior (e.g. cross-selling, upselling)

6A2 Experimental analytics: Design tests and experiments to assess consumer $\mathrm{o}_{-}+\mathrm{o}$ preferences (e.g. regarding channel preferences or pricing)

6A3 Real-time interaction: Offer consumer advisory based on real-time consumer information and business rules

6B1 Omnichannel revenues: Control the revenues generated by omnichannel approaches (growth and cannibalization effects)

6B2 Consumer funnel metrics: Monitor usage of touchpoints across buying phases (e.g. in comparison to competitors)

7A1 Assessment of analytical scenarios: Assess the potential value of data and analytical scenarios for omnichannel services

7A2 Analytics prototypes: Launch omnichannel service pilots to test and learn data potential

7B1 Data demand management: Implement data acquisition management consisting of (among others) data requirements management, data valuation and omnichannel data-flow analyses

7B2 Data quality management: Manage consumer data quality across customer ++++ channels and take into account future data demand and technology evolution 
Table 4 continued

\begin{tabular}{|c|c|c|c|c|c|}
\hline $\begin{array}{l}\text { T3 } \\
\text { ID }\end{array}$ & Practice: description & $\mathrm{R}$ & $\mathrm{C}$ & $\mathrm{F}$ & B \\
\hline $7 \mathrm{~B} 3$ & $\begin{array}{l}\text { Consumer data integration: Create and manage consumer data integration } \\
\text { architectures across channels (incl. consumer data models, data integration } \\
\text { layers, and data virtualization approaches) }\end{array}$ & + & + & + & + \\
\hline 8A1 & $\begin{array}{l}\text { Service partnerships: Evaluate, engage in and manage strategic partnerships } \\
\text { to design innovative omnichannel services }\end{array}$ & + & + & + & + \\
\hline $8 \mathrm{~A} 2$ & $\begin{array}{l}\text { Distribution partnerships: Partner with distributors or third party service } \\
\text { providers to access new distribution channels }\end{array}$ & - & o & + & + \\
\hline $8 \mathrm{~A} 3$ & $\begin{array}{l}\text { Technology partnerships: Partner with technology companies to access and } \\
\text { incorporate channel technology innovations }\end{array}$ & + & + & + & + \\
\hline $8 B 1$ & $\begin{array}{l}\text { Trend analysis: Regularly perform a screening of technologies and } \\
\text { omnichannel approaches on a global scale (e.g. technology trend radar, } \\
\text { startup market analyses) }\end{array}$ & + & + & + & o \\
\hline $8 \mathrm{~B} 2$ & $\begin{array}{l}\text { Benchmarking: Compare yourself with competitors to assess the adoption of } \\
\text { omnichannel approaches (including channel blending, pricing, and } \\
\text { bundling strategies) }\end{array}$ & + & + & + & + \\
\hline
\end{tabular}

T3 IDTier 3 ID, + strong evidence, $o$ partial evidence, - no evidence, $R$ retail company (market: national European; interviewees: head of customer intelligence, head digital channels), $C$ consumer goods company (market: global; interviewees: data management lead, manager product information management), $F$ financial services company (market: national European; interviewees. Head IT strategy, manager IT planning), $B$ bank (market: national European; interviewees: head enterprise architecture, head IT architecture, manager digital services)

architecture informed us that, because of positive experiences, an internal prototyping team is currently being established. Since the assimilation of consumer-centric design practices, in this case, is premature, we coded the case evidence as "partial". The practice of agile service management (Tier 3 ID: 1B2) addresses the application of methods to enable flexibility and speed in service development and operations. In all case studies, agile software development methods (e.g. Scrum in Case B) were used for an agile development of omnichannel services. The practice innovation management (Tier 3 ID: 1B3) covers methods to stimulate innovations. Both interviewees at the consumer goods company (Case C), for example, reported that the use of crowdsourcing platforms successfully generated ideas for omnichannel design and marketing. In the retailer case (Case $\mathrm{R})$, several employees participate in omnichannel research projects in order to receive inspirations from outside the company.

\section{Demonstration and evaluation}

For evaluation purposes, we studied the application of the developed AHP hierarchy in a demonstration case at the global automobile manufacturer AutoCo. ${ }^{3}$ The development of omnichannel capabilities was part of a wider transformation

\footnotetext{
${ }^{3}$ We use a pseudonym for confidentiality reasons.
} 
program at AutoCo with the objective to harness digital services and improve customer experience, AutoCo's value propositions, and operational efficiency.

We focused on the following evaluation criteria proposed by March and Smith (1995) as well as Sonnenberg and vom Brocke (2012): (1) completeness, (2) level of detail, (3) fidelity with real-world phenomena, (4) internal consistency, (5) robustness, (6) effectivity and efficiency, and (7) impact on the artifact environment. We gathered data from various preparation calls, interviews with six executive managers (average duration: $60 \mathrm{~min}$ ), and a 90-minute focus group workshop.

1. Completeness We used two strategies in order to assess the completeness of the AHP hierarchy. First, we compared our solution to the solution requirements that were collected in the initial focus group (see Sect. 4.1). The identified capabilities fully cover outside-in, inside-out, and spanning capabilities for customer-data-driven as well as channel-technology-driven innovation (see Appendix 1, last gray-shaded row). Second, we conducted expert interviews in the course of the demonstration case. The interviewed subject matter experts (SMEs) occupied executive management positions in business areas relevant for omnichannel management (Chief Marketing Officer, Chief Information Officer, Head of Product Development, Head of Strategy, Head of Sales, and Head of Customer Experience). Prior to the interviews, we sent the SMEs a documentation of the AHP hierarchy and asked for missing capabilities and practices. During the interviews, we received further feedback on model completeness. No SME criticized missing capabilities or practices.

2. Level of detail In addition to completeness, we further asked for feedback on the hierarchy's level of detail. SMEs selectively brought up a few issues regarding a coarse-grained level of detail, all of which were jointly discussed and dropped due to model complexity trade-offs. For example, the CIO noted that the frontend reconfiguration capability (Tier 3 ID: 3A1) is very general. However, we jointly concluded that a fine-grained listing of reconfiguration capabilities would go beyond the scope of the AHP hierarchy. As a second example, the CMO noted that the business orientation capability (Tier 2 ID: 6B) is purely focused on monitoring the status quo, but not on the implementation of the multichannel strategy. In a joint discussion, however, we concluded that strategy implementation is subject to the initiative coordination capability (Tier 2 ID: 2B) and that a more detailed analysis of implementation aspects would lead to disproportional model complexity. We resolved one issue regarding a too fine-grained level of detail in the interviews. The CIO noted that including concrete examples, such as a Chief Digital Officer, in the key roles practice (Tier 3 ID: 5A1) would be an overgeneralization. Hence, we removed these examples.

3. Fidelity with real-world phenomena In the interviews with each SME, we collected relative comparisons on tiers one, two and three of the AHP hierarchy. We used Saaty's scale $(1=$ indifference to $9=$ extreme preference) (Saaty 1990) to measure the relative ratings of a decision factor in comparison to another factor. We validated that all factors are independent of other factors on the same tier and on superordinate tiers, which is a precondition for the AHP 
methodology (Saaty 2005). For example, the implementation of each omnichannel practice on hierarchy tier three does not affect the implementation of other omnichannel practices; neither is a practice influenced by omnichannel capabilities at hierarchy tier two. We subsequently calculated the local factor weights for each SME with the geometric mean method (Crawford and Williams 1985). Subsequently, we calculated the global weights for each factor and SME individually as composites of local weights following the procedure described by Saaty and Vargas (2012, p. 33). Based on the results of the factor weighting procedure, we assess fidelity with real-world phenomena as follows.

The weights signal the relative importance of a factor for an SME. If a factor is given medium to high importance by at least one SME, we consider this as evidence that this factor is legitimately included in the AHP hierarchy. Since no factor consistently received low importance (see Appendix 2), we conclude that all factors contribute to the operationalization of omnichannel capabilities at AutoCo. Factor importance and factor completeness conjunctively support the hierarchy's fidelity with real-world phenomena, i.e. the hierarchy's ability to capture all factors that constitute omnichannel capabilities at AutoCo.

4. Internal consistency For each SME, we validated the consistency of the matrices of pairwise comparisons by means of the consistency ratio (Alonso and Lamata 2006). Most comparison matrices involve only one or three comparisons. One comparison naturally results in perfect consistency. Three comparisons generate relatively low cognitive effort for raters to naturally reach high consistency (Miller, 1994). We thus could successfully verify that all consistency ratios are below the proposed threshold of $\mathrm{CR}(\mathrm{A})=0.1$ (Alonso and Lamata 2006) for all comparison matrices of the individual SMEs. For each cluster of factors that relate to the same parent factor, we report the maximum of the six SMEs' consistency ratios in Table 5. Full rating consistency provides strong evidence for the internal consistency of the AHP hierarchy.

5. Robustness After calculating the individual SMEs' weights, the weights were aggregated and a joint calibration was carried out. In order to generate aggregates from the local weights of the individual SMEs (aggregated local weights), we used the AIP (aggregation of individual properties) approach (Bernasconi et al. 2014). We calculated the geometric mean of the individual judges' local weights for each factor in a cluster of factors that belong to the same parent factor. By normalizing the geometric means for a cluster, we receive the factors' aggregated local weights. We then calculated the aggregated global weight of a factor by multiplying this factor's aggregated local weight with the aggregated global weight of the parent factor, as described by Saaty and Vargas (2012, p. 33). Table 5 reports the aggregated local and global weights. In a closing workshop with the participating executive managers, the aggregated results were discussed. There was a large consensus about the prioritization logic that is carried by the weighted factors in the AHP hierarchy. The six SMEs represent diverse business functions at AutoCo. The fact that all SMEs asserted hierarchy completeness and fidelity with the real word is a first evidence for cross-functional hierarchy robustness. The 


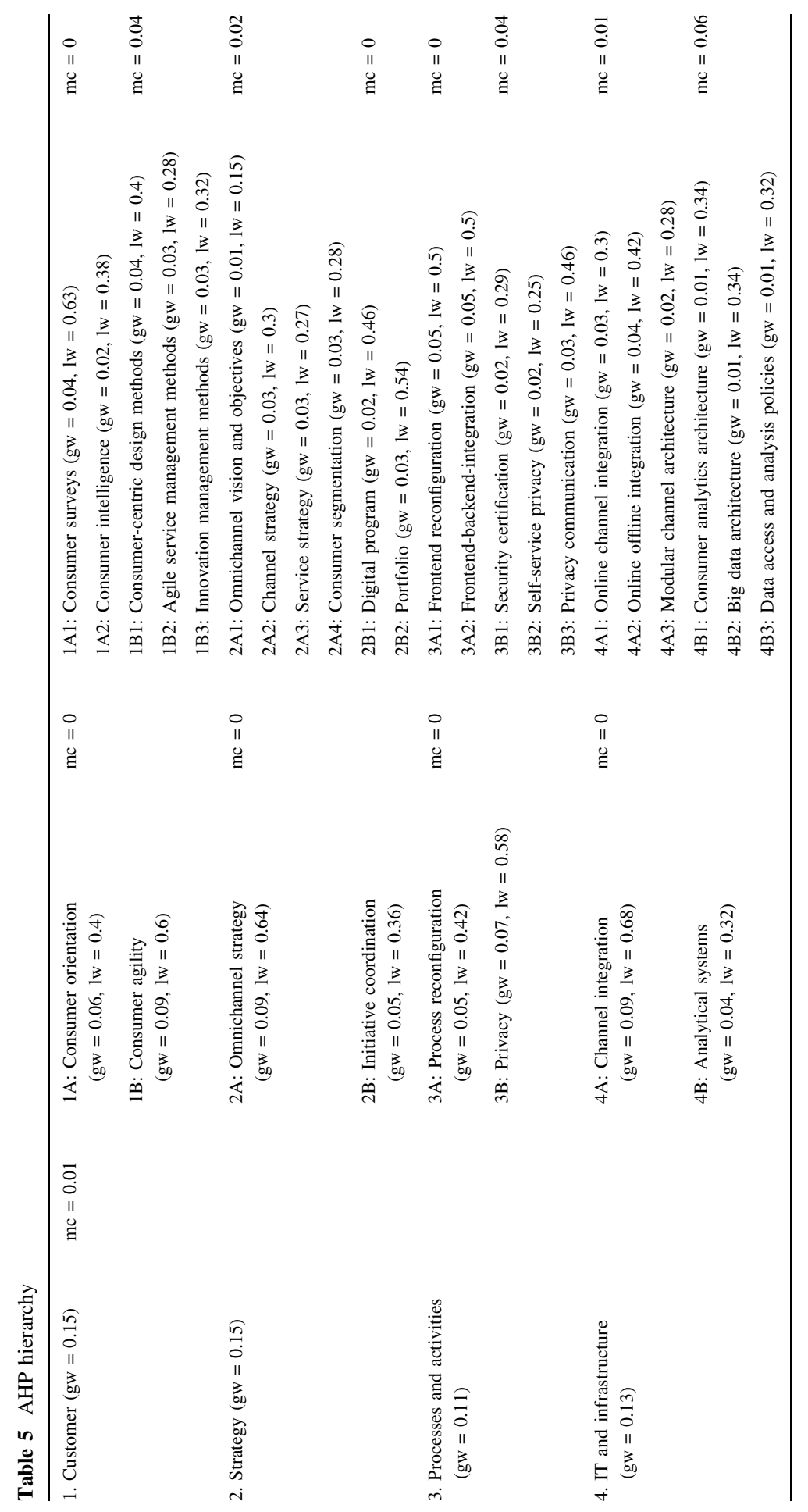




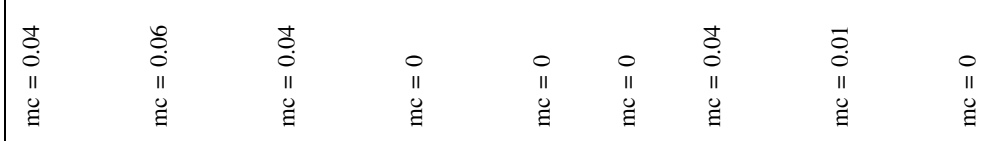

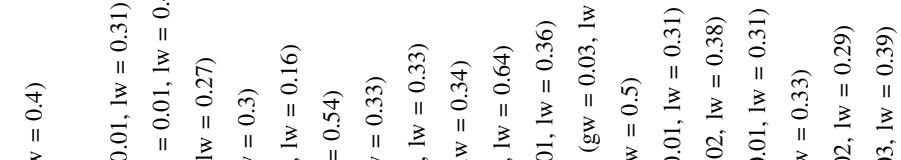

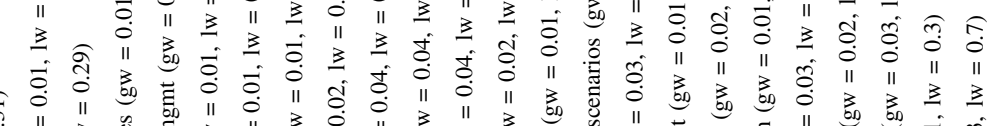

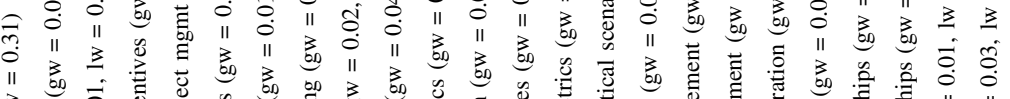

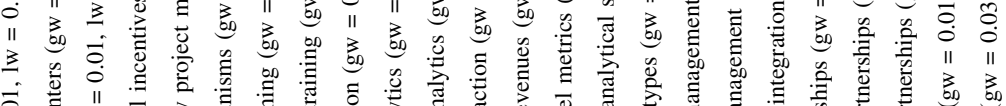

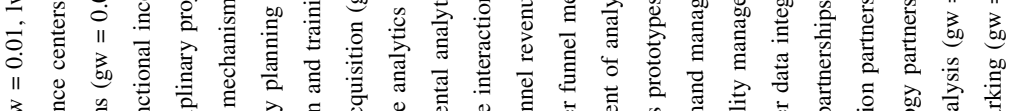

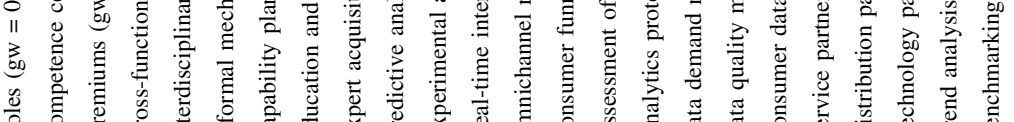

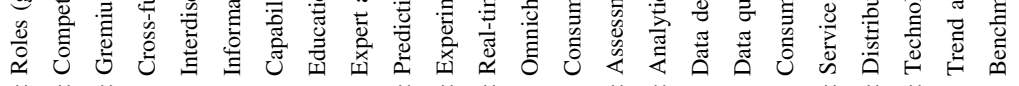

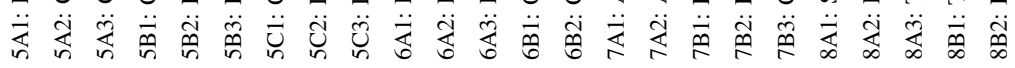

II

$\circ$
II

II
$\dddot{y}$

II
$\ddot{g}$

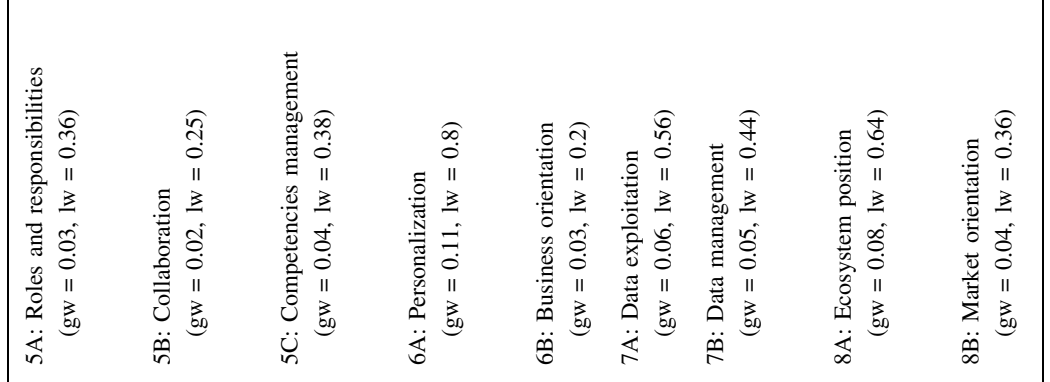

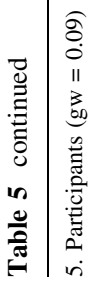

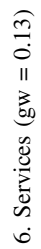
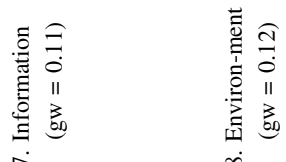

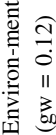

$\infty$

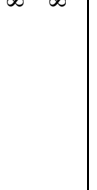


consensus of the representatives of diverse business functions about the aggregated factor weights shows that all representatives consider their company-function-oriented standpoints sufficiently reflected by the aggregated factor weights and further asserts the hierarchy's cross-functional robustness.

6. Effectiveness and efficiency Regarding the effectiveness of using the AHP hierarchy for knowledge acquisition, the SMEs highlighted two aspects in the closing workshop's feedback discussion. First, the AHP hierarchy provided shared semantics to discuss and prioritize omnichannel capabilities. For instance, according to the head of strategy, managers in different company functions tend to have inconsistent understandings of core concepts in omnichannel management due to their distinct professional backgrounds. The definitions provided in the model helped to create a common vocabulary that was essential to jointly agree on capability prioritization.

Second, the aggregation of proven practices from multiple $\mathrm{B} 2 \mathrm{C}$ organizations during model synthesis resulted in a collection of actionable practices. For instance, according to the head of sales, the presentation of practical application examples that we gathered during model synthesis increased the hierarchy's inspirational power and facilitated knowledge acquisition in AutoCo's context.

Regarding the efficiency of using the AHP hierarchy for knowledge acquisition, the SMEs particularly mentioned the model's parsimony. For instance, according to the $\mathrm{CIO}$, compared to capability models in other domains, the AHP hierarchy focuses on a manageable set of factors. As a consequence, it was possible to conduct factor weighting with reasonable effort. However, the SMEs considered interviewer guidance during the factor prioritization interviews indispensable and advised against implementing a survey-based assessment approach.

7. Impact on the artifact environment The assessment and calibration of the AHP hierarchy supported two tasks at AutoCo: assessment of capability strengths and weaknesses as well as enabling the assessment of further capability management activities. Regarding the assessment of capability strengths and weaknesses, the results of AHP hierarchy calibration were reported to the executive board to inform about and receive buy-in for future omnichannel capability development. Regarding the assessment of further capability management activities, the calibrated AHP hierarchy informed the decision of which capability projects to further invest in. The support of both tasks provides evidence that the AHP hierarchy had a constructive influence on capability management at AutoCo.

\section{Conclusion}

\subsection{Limitations}

Our results and implications must be interpreted with caution regarding the following aspects. First, the applicability of the hierarchy is limited by our selection 
of key informants and cases. Particularly, the results exclusively apply to omnichannel management at B2C organizations and are not transferable to B2B organizations. Although we provide evidence for the model's robustness across different organizational functions, further research should evaluate the model's application in other organizational contexts. Second, there is a risk that we did not sufficiently capture facets of omnichannel capability in the expert interviews and case studies. In order to secure construct validity, we followed the guidelines by Yin (2013, p. 34). We used triangulation with multiple sources during data analysis and we asked the key informants to review the written interview summaries. Third, there is a risk of unwarranted conclusions on the organization-level effects of applying the AHP hierarchy in the demonstration case. In order to address threats to internal validity owing to the selection of key informants (Brewer and Crano 2014, p. 13), we only chose executive managers with a sufficient level of company oversight in our demonstration case. Further, we took care to select representatives from all customer-facing company functions.

\subsection{Contributions to theory}

We contribute to the literature on omnichannel capabilities in the following ways. First, our proposed AHP hierarchy theoretically bases on prior omnichannel literature (Beck and Rygl 2015; Verhoef et al. 2015) and the service system framework (Alter 2008, 2011) to define a three-tier structure of omnichannel capabilities. With the developed AHP hierarchy, we address the lack of formalized capability models and support capability management in the knowledge acquisition phase (Rauffet et al. 2012, 2016) by providing systemized knowledge in the form of practice and capability descriptions. The hierarchy further provides the foundation for implementing an AHP method and thus indirectly supports the subsequent capability management phases. This research, however, focused on the development and validation of an AHP hierarchy and thus primarily addresses the knowledge acquisition phase of capability management. Future research should apply this AHP hierarchy to implement an AHP method for omnichannel capability management in the knowledge adaptation, application, and appropriation phases. Such a method supports the assessment and prioritization of several independent decision alternatives.

Second, to our knowledge, this is the first study in the field of omnichannel management that conducts DSR and produces an artifact that supports the acquisition of knowledge in omnichannel capability management. Prior literature produces explanatory (e.g. Hansen and Sia 2015) and predictive (e.g. Luo et al. 2016) theories but lacks theories for design and action that address urgent management demands to improve omnichannel capabilities (Econsultancy 2013; Frost \& Sullivan 2015; Ovum 2017). We address this lack of theory for design and action and show in a demonstration case how the AHP hierarchy can be applied in order to familiarize executive managers with omnichannel practices and to guide the process of setting priorities for capability development. Future research should, in turn, generate explanatory theory and analyze the long-term effects of capability management on omnichannel service performance. 


\subsection{Contributions to practice}

Our contribution to practice is twofold. First, the developed hierarchy accumulates good practices from a variety of $\mathrm{B} 2 \mathrm{C}$ organizations and consumer markets. Thus, the hierarchy represents a reference model for omnichannel capabilities, which can inspire managers regarding how to improve omnichannel capabilities in their organizations. Second, the AHP hierarchy is an actionable management instrument that can readily be used by $\mathrm{B} 2 \mathrm{C}$ organizations to implement factor weighting and an AHP method for omnichannel capability management. An AHP method flexibly supports, for example, the selection and steering of projects for omnichannel capability development or the comparison of organizations' capability maturities.

Open Access This article is distributed under the terms of the Creative Commons Attribution 4.0 International License (http://creativecommons.org/licenses/by/4.0/), which permits unrestricted use, distribution, and reproduction in any medium, provided you give appropriate credit to the original author(s) and the source, provide a link to the Creative Commons license, and indicate if changes were made.

\section{Appendix 1}

See Table 6. 
Table 6 Results of literature assessment

\begin{tabular}{|c|c|c|c|c|c|c|c|c|}
\hline & \multirow{2}{*}{\begin{tabular}{|l|}
$\begin{array}{l}\text { Outside - In ca- } \\
\text { pabilities }\end{array}$ \\
$\begin{array}{l}\text { Customer-data- } \\
\text { driven innova- } \\
\text { tion }\end{array}$ \\
\end{tabular}} & \multirow{2}{*}{ 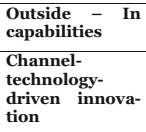 } & \multirow{2}{*}{\begin{tabular}{|l|}
$\begin{array}{l}\text { Inside-Out } \\
\text { capabilities }\end{array}$ \\
Customer- \\
data-driven \\
innovation
\end{tabular}} & \multirow{2}{*}{\begin{tabular}{|l|}
$\begin{array}{l}\text { Inside-Out } \\
\text { capabilities }\end{array}$ \\
Channel- \\
technology- \\
driven inno.
\end{tabular}} & \multirow{2}{*}{$\begin{array}{l}\begin{array}{l}\text { Spanning ca- } \\
\text { pabilities }\end{array} \\
\begin{array}{l}\text { Customer- } \\
\text { data-driven } \\
\text { innovation }\end{array} \\
\end{array}$} & \multirow{2}{*}{\begin{tabular}{|l|}
$\begin{array}{l}\text { Spanning capabil- } \\
\text { ities }\end{array}$ \\
$\begin{array}{l}\text { Channel- } \\
\text { technology-driven } \\
\text { innovation }\end{array}$ \\
\end{tabular}} \\
\hline & $\mathbf{M}^{1}$ & Scope & & & & & & \\
\hline 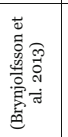 & $\mathrm{CS}$ & $\begin{array}{l}\text { Short-term and } \\
\text { long-term strate- } \\
\text { gies for dual- } \\
\text { channel, brick- } \\
\text { and-mortar, and } \\
\text { pure online retail- } \\
\text { ers }\end{array}$ & $\begin{array}{l}\text { Big data and ana- } \\
\text { lytics to understand } \\
\text { customer }\end{array}$ & $\begin{array}{l}\text { Create exclusive } \\
\text { products and } \\
\text { unique features }\end{array}$ & None & $\begin{array}{l}\text { Integrate chan- } \\
\text { nels }\end{array}$ & $\begin{array}{l}\text { Use analytics to } \\
\text { guide product } \\
\text { design }\end{array}$ & Local pickup \\
\hline 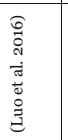 & $\mathrm{Su}$ & $\begin{array}{l}\text { Three dimensions: } \\
\text { e-commerce ca- } \\
\text { pabilities, cross- } \\
\text { channel fulfill- } \\
\text { ment capabilities, } \\
\text { and cross-selling } \\
\text { capabilities }\end{array}$ & None & None & None & $\begin{array}{l}\text { E-commerce } \\
\text { capabilities }\end{array}$ & None & $\begin{array}{l}\text { Cross-channel ful- } \\
\text { fillment capabilities } \\
\text { and cross-selling } \\
\text { capabilities }\end{array}$ \\
\hline 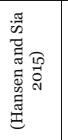 & CS & 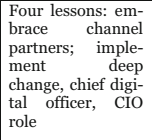 & None & $\begin{array}{l}\text { Embrace channel } \\
\text { partners }\end{array}$ & None & None & None & $\begin{array}{l}\text { CEO commitment; } \\
\text { internal communica- } \\
\text { tion; omnichannel } \\
\text { mindset; digital de- } \\
\text { partment, CIO ena- } \\
\text { blement }\end{array}$ \\
\hline 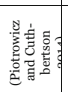 & FG & $\begin{array}{l}\text { Six important } \\
\text { areas regarding IT } \\
\text { impact in retail }\end{array}$ & $\begin{array}{l}\text { Personalization vs. } \\
\text { privacy }\end{array}$ & $\begin{array}{l}\text { Role of social me- } \\
\text { dia; diverse cus- } \\
\text { tomer require- } \\
\text { ments }\end{array}$ & None & $\begin{array}{ll}\text { In-store } & \text { tech- } \\
\text { nologies } & \end{array}$ & None & 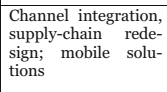 \\
\hline 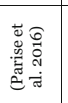 & IS & $\begin{array}{l}\text { Success factors for } \\
\text { remote product } \\
\text { expert and digital } \\
\text { assistant }\end{array}$ & $\begin{array}{l}\text { User-value vs pri- } \\
\text { vacy tradeoff }\end{array}$ & $\begin{array}{ll}\begin{array}{l}\text { Deliver } \\
\text { multiple }\end{array} & \text { across } \\
\text { points } & \text { touch- }\end{array}$ & None & \begin{tabular}{l}
\multicolumn{2}{l}{ Leverage chan- } \\
nel technolo- \\
gies; Trained \\
staff
\end{tabular} & $\begin{array}{l}\text { Touchpoint } \\
\text { analysis; Cus- } \\
\text { tomer personas; } \\
\text { Iterative devel- } \\
\text { opment }\end{array}$ & None \\
\hline 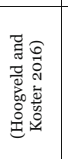 & LA & $\begin{array}{l}\text { Four organiza- } \\
\text { tional factors for } \\
\text { omnichannel per- } \\
\text { formance: strate- } \\
\text { gy, people, organi- } \\
\text { zational structure, } \\
\text { and information } \\
\text { systems }\end{array}$ & None & $\begin{array}{l}\text { Multichannel } \\
\text { strategy }\end{array}$ & $\begin{array}{l}\text { Integrated } \\
\text { CRM }\end{array}$ & $\begin{array}{l}\text { Consistent in- } \\
\text { formation } \\
\text { across channels }\end{array}$ & $\begin{array}{l}\text { Effective pro- } \\
\text { cesses for col- } \\
\text { lecting and re- } \\
\text { sponding to } \\
\text { customer feed- } \\
\text { back }\end{array}$ & $\begin{array}{l}\text { Cross-functional } \\
\text { collaboration; cus- } \\
\text { tomer-centric organ- } \\
\text { ization }\end{array}$ \\
\hline 这的 & Su & $\begin{array}{l}\text { Operations and } \\
\text { logistics compe- } \\
\text { tencies }\end{array}$ & None & None & None & $\begin{array}{l}\text { Integration of } \\
\text { offline and } \\
\text { online invento- } \\
\text { ry systems }\end{array}$ & $\begin{array}{l}\text { Integration of } \\
\text { channel units }\end{array}$ & $\begin{array}{l}\text { Integration of opera- } \\
\text { tional channel units; } \\
\text { integrated opera- } \\
\text { tional processes }\end{array}$ \\
\hline 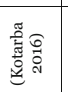 & $\mathrm{Ar}$ & $\begin{array}{l}\text { Proposed actions } \\
\text { to address } \\
\text { omnichannel chal- } \\
\text { lenges }\end{array}$ & None & $\begin{array}{l}\text { Risk evaluation; } \\
\text { digitalization } \\
\text { strategy; ecosys- } \\
\text { tem approach }\end{array}$ & \begin{tabular}{|l|} 
Analytical \\
capabilities
\end{tabular} & $\begin{array}{l}\text { Tech-savvy HR; } \\
\text { agile infrastruc- } \\
\text { ture }\end{array}$ & $\begin{array}{l}\text { Customer seg- } \\
\text { mentation; cus- } \\
\text { tomer journey } \\
\text { research }\end{array}$ & $\begin{array}{l}\text { Synchronization of } \\
\text { client facing compo- } \\
\text { nents; digital office }\end{array}$ \\
\hline 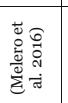 & LA & $\begin{array}{l}\text { Key challenges to } \\
\text { improve the cus- } \\
\text { tomer experience } \\
\text { in an omnichannel } \\
\text { environment }\end{array}$ & $\begin{array}{l}\text { Personalized } \\
\text { experiences }\end{array}$ & None & $\begin{array}{l}\text { Customer data } \\
\text { integration }\end{array}$ & $\begin{array}{l}\text { Unify all touch- } \\
\text { points, embrace } \\
\text { mobile chan- } \\
\text { nels }\end{array}$ & None & $\begin{array}{l}\text { Customer-centric } \\
\text { approach, cross- } \\
\text { channel integration }\end{array}$ \\
\hline 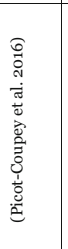 & CS & $\begin{array}{l}\text { Strategy-related } \\
\text { and development } \\
\text { related challenges } \\
\text { and ways of ad- } \\
\text { dressing them }\end{array}$ & $\begin{array}{l}\text { Understanding } \\
\text { customer journeys }\end{array}$ & $\begin{array}{l}\text { Homogenizing } \\
\text { brand, price, and } \\
\text { channels }\end{array}$ & None & $\begin{array}{l}\text { Developing } \\
\text { training session } \\
\text { for salespeople; } \\
\text { staffing; sys- } \\
\text { tems and CRM } \\
\text { integration }\end{array}$ & None & $\begin{array}{l}\text { Implementing cross- } \\
\text { functional and } \\
\text { transversal man- } \\
\text { agement; developing } \\
\text { a shared internal } \\
\text { culture; holistic } \\
\text { management; defin- } \\
\text { ing the level of flexi- } \\
\text { bility of the retailing } \\
\text { mix; leveraging fi- } \\
\text { nancial resources to } \\
\text { support the opera- } \\
\text { tions }\end{array}$ \\
\hline
\end{tabular}


Table 6 continued

\begin{tabular}{|c|c|c|c|c|c|c|c|c|c|c|c|c|c|c|}
\hline & & & $\begin{array}{l}\text { Outside - } \\
\text { pabilities }\end{array}$ & n ca- & $\begin{array}{l}\text { Outs } \\
\text { capal }\end{array}$ & $\begin{array}{ll}\text { de }- & \text { In } \\
\text { ilitities } & \end{array}$ & $\begin{array}{l}\text { Inside-C } \\
\text { capabili }\end{array}$ & $\begin{array}{l}\text { tut } \\
\text { ties }\end{array}$ & $\begin{array}{l}\text { Ins } \\
\text { cap }\end{array}$ & $\begin{array}{l}\text { e-Out } \\
\text { bilities }\end{array}$ & $\begin{array}{l}\text { Spannin } \\
\text { pabilitie }\end{array}$ & ca- & \begin{tabular}{|l} 
Spann \\
ities
\end{tabular} & ng capabil- \\
\hline & $\mathbf{M}^{1}$ & Scope & $\begin{array}{l}\text { Customer- } \\
\text { driven is } \\
\text { tion }\end{array}$ & ata- & $\begin{array}{l}\text { Chan } \\
\text { techr } \\
\text { drive } \\
\text { tion }\end{array}$ & $\begin{array}{l}\text { nel- } \\
\text { ology- } \\
\text { n innova- }\end{array}$ & $\begin{array}{l}\text { Custom } \\
\text { data-dri } \\
\text { innovat }\end{array}$ & $\begin{array}{l}\text { er- } \\
\text { ven } \\
\text { ion }\end{array}$ & & $\begin{array}{l}\text { inel- } \\
\text { cology- } \\
\text { en inno. }\end{array}$ & $\begin{array}{l}\text { Custome } \\
\text { data-dri } \\
\text { innovati }\end{array}$ & & $\begin{array}{l}\text { Chann } \\
\text { techno } \\
\text { innove }\end{array}$ & $\begin{array}{l}\text { l- } \\
\text { logy-driven } \\
\text { tion }\end{array}$ \\
\hline 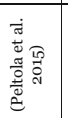 & IS & $\begin{array}{l}\text { Factors influenc- } \\
\text { ing unified cus- } \\
\text { tomer experience } \\
\text { and seamless } \\
\text { touchpoint con- } \\
\text { nections }\end{array}$ & None & & $\begin{array}{l}\text { Unifie } \\
\text { and } \\
\text { forma } \\
\text { comm }\end{array}$ & $\begin{array}{l}\text { d pricing } \\
\text { product in- } \\
\text { tion; unified } \\
\text { unications }\end{array}$ & None & & $\begin{array}{l}\text { Tou } \\
\text { inte }\end{array}$ & $\begin{array}{l}\text { point } \\
\text { ation }\end{array}$ & None & & $\begin{array}{l}\text { Organiz } \\
\text { cultura } \\
\text { bility in } \\
\text { logistic }\end{array}$ & $\begin{array}{l}\text { ational and } \\
\text { unity; Flexi- } \\
\text { systems and }\end{array}$ \\
\hline 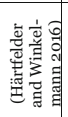 & LA & $\begin{array}{l}\text { Key opportunities } \\
\text { and challenges in } \\
\text { a mobile internet } \\
\text { device-dominated } \\
\text { retailer environ- } \\
\text { ment }\end{array}$ & $\begin{array}{l}\text { Mobile reco } \\
\text { dation agen } \\
\text { ta-driven } \\
\text { ing; privacy }\end{array}$ & $\begin{array}{l}\text { amen- } \\
\text {; da- } \\
\text { arket- }\end{array}$ & $\begin{array}{l}\text { Seam } \\
\text { ence }\end{array}$ & ess experi- & None & & Nor & & $\begin{array}{l}\text { Track an } \\
\text { lyze data }\end{array}$ & ana- & $\begin{array}{l}\text { Cross-c } \\
\text { ing; } \\
\text { departn } \\
\text { tion; }\end{array}$ & $\begin{array}{r}\text { trannel track- } \\
\text { cross- } \\
\text { tent integra- }\end{array}$ \\
\hline 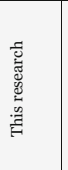 & DS & $\begin{array}{l}\text { AHP hierarchy of } \\
\text { omnichannel ca- } \\
\text { pabilities }\end{array}$ & $\begin{array}{l}\text { 1A: Con- } \\
\text { sumer ori- } \\
\text { entation; } \\
\text { 3B: Privacy; } \\
\text { 6A: Person- } \\
\text { alization }\end{array}$ & $\begin{array}{l}8 \mathrm{~A}: \mathrm{E} \\
\text { tem p } \\
\text { tion; } \\
8 \mathrm{~B}: \mathrm{M} \\
\text { orient } \\
5 \mathrm{C}: \mathrm{C} \\
\text { tencie } \\
\text { mana } \\
\text { ment }\end{array}$ & $\begin{array}{l}\text { cosys- } \\
\text { osi- } \\
\text { larket } \\
\text { ation } \\
\text { ompe- } \\
\text { s } \\
\text { ge- }\end{array}$ & $\begin{array}{l}\text { 6B: Busi- } \\
\text { ness orien- } \\
\text { tation; } \\
2 \mathrm{~A} \text { : Omni- } \\
\text { channel } \\
\text { strategy }\end{array}$ & $\begin{array}{l}\text { 4B: } \\
\text { Analyti- } \\
\text { cal sys- } \\
\text { tems }\end{array}$ & $\begin{array}{l}7 \mathrm{~B}: \mathrm{D} \\
\text { mana } \\
\text { ment }\end{array}$ & & $\begin{array}{l}\text { 4A: } \\
\text { Channel } \\
\text { integra- } \\
\text { tion }\end{array}$ & $\begin{array}{l}\text { 7A: Data } \\
\text { exploita- } \\
\text { tion }\end{array}$ & $\begin{array}{l}1 \mathrm{~B}: \mathrm{Co} \\
\text { er agil } \\
2 \mathrm{~B}: \mathrm{In} \\
\text { coord } \\
5 \mathrm{~A}: \mathrm{R} \\
\text { respo } \\
\text { ties; } \\
5 \mathrm{~B}: \mathrm{Cc} \\
\text { ration }\end{array}$ & $\begin{array}{l}\text { onsum- } \\
\text { lity; } \\
\text { hitiative } \\
\text { ination; } \\
\text { oles and } \\
\text { nsibili- } \\
\text { ollabo- }\end{array}$ & $\begin{array}{l}\text { 3A: Process } \\
\text { reconfigu- } \\
\text { ration }\end{array}$ \\
\hline
\end{tabular}

\section{Appendix 2}

See Table 7.

Table 7 Global factor weights on tier 3 (practices) for the six experts

\begin{tabular}{lllllll}
\hline PID & HSA $(\%)$ & HPD $(\%)$ & HCE $(\%)$ & CIO $(\%)$ & CMO $(\%)$ & HST $(\%)$ \\
\hline 1A1 & 3.67 & 6.39 & 0.57 & 2.48 & 3.13 & 3.60 \\
1A2 & 3.67 & 2.13 & 0.57 & 0.83 & 3.13 & 1.20 \\
1B1 & 0.38 & 1.29 & 3.64 & 5.51 & 11.94 & 1.51 \\
1B2 & 0.94 & 0.26 & 0.60 & 5.51 & 4.84 & 3.72 \\
1B3 & 0.15 & 1.29 & 1.47 & 5.51 & 1.96 & 9.17 \\
2A1 & 0.83 & 0.24 & 1.19 & 1.86 & 1.16 & 3.25 \\
2A2 & 4.81 & 0.61 & 1.19 & 5.58 & 3.47 & 2.08 \\
2A3 & 4.81 & 0.61 & 3.58 & 1.86 & 1.16 & 3.25 \\
2A4 & 1.86 & 1.59 & 3.58 & 5.58 & 1.16 & 1.02 \\
2B1 & 2.05 & 0.76 & 4.77 & 2.48 & 0.69 & 4.80 \\
2B2 & 2.05 & 2.29 & 4.77 & 2.48 & 0.69 & 4.80 \\
3A1 & 0.68 & 2.84 & 4.77 & 1.15 & 3.47 & 0.72 \\
3A2 & 2.05 & 2.84 & 4.77 & 0.38 & 3.47 & 0.72 \\
3B1 & 3.53 & 1.89 & 4.34 & 0.66 & 0.46 & 0.86 \\
3B2 & 1.43 & 1.89 & 0.87 & 1.98 & 0.46 & 0.86 \\
3B3 & 8.70 & 1.89 & 4.34 & 1.98 & 0.46 & 2.58 \\
4A1 & 2.45 & 0.34 & 6.82 & 2.97 & 2.31 & 1.55 \\
4A2 & 2.45 & 0.61 & 2.27 & 8.92 & 2.31 & 4.64 \\
4A3 & 2.45 & 0.19 & 6.82 & 2.97 & 2.31 & 1.55 \\
4B1 & 0.49 & 4.38 & 0.60 & 2.12 & 0.46 & 0.86 \\
\hline
\end{tabular}


Table 7 continued

\begin{tabular}{lllllll}
\hline PID & HSA $(\%)$ & HPD $(\%)$ & HCE $(\%)$ & CIO $(\%)$ & CMO $(\%)$ & HST $(\%)$ \\
\hline 4B2 & 0.49 & 1.46 & 2.33 & 0.71 & 0.46 & 0.86 \\
4B3 & 0.49 & 4.38 & 0.26 & 2.12 & 0.46 & 0.86 \\
5A1 & 0.26 & 0.74 & 0.24 & 1.58 & 0.93 & 3.53 \\
5A2 & 0.63 & 2.21 & 1.45 & 0.53 & 0.93 & 1.18 \\
5A3 & 0.10 & 2.21 & 0.59 & 0.53 & 0.93 & 3.53 \\
5B1 & 0.33 & 0.34 & 0.33 & 0.25 & 0.93 & 3.74 \\
5B2 & 0.33 & 0.34 & 0.98 & 0.57 & 0.93 & 3.74 \\
5B3 & 0.33 & 0.34 & 0.98 & 0.06 & 0.93 & 0.75 \\
5C1 & 0.33 & 1.33 & 0.76 & 1.13 & 0.56 & 0.91 \\
5C2 & 0.33 & 0.54 & 0.76 & 0.38 & 0.56 & 0.91 \\
5C3 & 2.32 & 3.29 & 0.76 & 1.13 & 1.67 & 0.91 \\
6A1 & 6.75 & 5.29 & 1.25 & 3.22 & 2.08 & 1.55 \\
6A2 & 6.75 & 5.29 & 1.25 & 3.22 & 2.08 & 1.55 \\
6A3 & 6.75 & 5.29 & 0.25 & 3.22 & 2.08 & 4.64 \\
6B1 & 3.37 & 4.41 & 0.23 & 0.69 & 1.04 & 1.93 \\
6B2 & 3.37 & 0.88 & 0.08 & 0.69 & 1.04 & 0.52 \\
7A1 & 2.20 & 2.29 & 4.77 & 4.60 & 2.08 & 1.29 \\
7A2 & 2.20 & 2.29 & 4.77 & 4.60 & 2.08 & 1.29 \\
7B1 & 2.64 & 0.16 & 3.18 & 0.26 & 1.39 & 2.58 \\
7B2 & 0.88 & 0.97 & 3.18 & 0.79 & 1.39 & 2.58 \\
7B3 & 0.88 & 0.39 & 3.18 & 0.79 & 1.39 & 2.58 \\
8A1 & 0.73 & 5.88 & 1.71 & 2.10 & 4.17 & 0.70 \\
8A2 & 0.73 & 5.88 & 1.71 & 0.42 & 4.17 & 1.28 \\
8A3 & 0.73 & 5.88 & 1.71 & 2.10 & 4.17 & 2.32 \\
8B1 & 0.83 & 1.76 & 0.43 & 0.26 & 6.25 & 0.36 \\
8B2 & 5.78 & 1.76 & 1.28 & 1.28 & 6.25 & 1.08 \\
\hline Valn & & & & & \\
\hline
\end{tabular}

Values given in italics indicate low relative importance, operationalized as the global factor weight being equal to or below the $25 \%$ quantile of the SME's weights

PID Practice ID, HSA head of sales, HPD head of product development, HCE head of customer experience, $C I O$ chief information officer, $C M O$ chief marketing officer, $H S T$ head of strategy

\section{References}

Accenture. 2013. Seamless retail—customize. Connect. Converge. Accenture Report. https://thelbma. com/wpcontent/uploads/files/404-Accenture-Seamless-Retail-Overview-Brochure.pdf.

Afflerbach, P., M. Bolsinger, and M. Röglinger. 2016. An economic decision model for determining the appropriate level of business process standardization. Business Research 9 (2): 335-375. https://doi. org/10.1007/s40685-016-0035-6.

Alonso, J.A., and M.T. Lamata. 2006. Consistency in the analytic hierarchy process: a new approach. International Journal of Uncertainty, Fuzziness and Knowledge-Based Systems 14 (04): 445-459.

Alter, S. 2008. Defining information systems as work systems: Implications for the IS field. European Journal of Information Systems 17 (5): 448-469. 
Alter, S. 2011. Metamodel for service design and service innovation: Integrating service activities, service systems, and value constellations. In: Proceedings of the International Conference on Information Systems, ICIS 2011, Shanghai, China, December 4-7, 2011.

Amit, R., and P.J. Schoemaker. 1993. Strategic assets and organizational rent. Strategic Management Journal 14 (1): 33-46.

Ashurst, C., N.F. Doherty, and J. Peppard. 2008. Improving the impact of IT development projects: The benefits realization capability model. European Journal of Information Systems 17 (4): 352-370.

Beck, N., and D. Rygl. 2015. Categorization of multiple channel retailing in multi-, cross-, and omnichannel retailing for retailers and retailing. Journal of Retailing and Consumer Services 27: $170-178$.

Bernasconi, M., C. Choirat, and R. Seri. 2014. Empirical properties of group preference aggregation methods employed in AHP: Theory and evidence. European Journal of Operational Research 232 (3): 584-592.

Blom, A., F. Lange, and R.L. Hess. 2017. Omnichannel-based promotions' effects on purchase behavior and brand image. Journal of Retailing and Consumer Services 39 (Supplement C): 286-295. https:// doi.org/10.1016/j.jretconser.2017.08.008.

Brewer, M.B., and W.D. Crano. 2014. Research design and issues of validity. In Handbook of research methods in social and personality psychology, eds. H. T. Reis \& C. M. Judd, (pp. 11-26). New York, NY, US: Cambridge University Press.

Brynjolfsson, E., Y.J. Hu, and M.S. Rahman. 2013. Competing in the age of omnichannel retailing. MIT Sloan Management Review 54 (4): 23.

Cleven, A.K., R. Winter, F. Wortmann, and T. Mettler. 2014. Process management in hospitals: an empirically grounded maturity model. Business Research 7 (2): 191-216. https://doi.org/10.1007/ s40685-014-0012-x.

Consumers feeling in a dilemma over Omnichannel - survey from PeriscopeTM, by McKinsey. 2016. IDMi (Information \& Document Management International). 47(94):6. https://search.ebscohost. com/login.aspx?direct=true \&db=bth\&AN=125619291\&site=ehost-live. Accessed 5 Mar 2019

Crawford, G., and C. Williams. 1985. A note on the analysis of subjective judgment matrices. Journal of Mathematical Psychology 29 (4): 387-405.

Econsultancy. 2013. Cross-channel marketing report. Econsultancy Report. https://www.econsultancy. com/reports/cross-channel-marketing-report-2013. Accessed 1 June 2015.

Eisenhardt, K.M. 1989. Building theories from case study research. Academy of Management Review 14 (4): 532-550.

Flavián, C., R. Gurrea, and C. Orús. 2016. Choice confidence in the webrooming purchase process: The impact of online positive reviews and the motivation to touch. Journal of Consumer Behaviour 15 (5): 459-476.

Frost \& Sullivan. 2015. Omnichannel customer experience-not an option, but a strategic necessity. Frost \& Sullivan. Report. https://www.tetherfi.com/wp-content/uploads/2015/10/tetherfi_whitepaper_ occe.pdf. Accessed 1 May 2016.

Gallino, S., and A. Moreno. 2014. Integration of online and offline channels in retail: The impact of sharing reliable inventory availability information. Management Science 60 (6): 1434-1451.

Grant, R.M. 1991. The resource-based theory of competitive advantage: implications for strategy formulation. California Management Review 33 (3): 114-135.

Gregor, S. 2006. The nature of theory in information systems. MIS Quarterly 30 (3): 611-642.

Gregor, S., and A.R. Hevner. 2013. Positioning and presenting design science research for maximum impact. MIS Quarterly 37 (2): 337-355.

Hansen, R., and S.K. Sia. 2015. Hummel's digital transformation toward omnichannel retailing: Key lessons learned. MIS Quarterly Executive 14 (2): Article 3. Available at: https://aisel.aisnet.org/ misqe/vol14/iss2/3.

Härtfelder, J., and A. Winkelmann. 2016. Opportunities and challenges for local retailing in an environment dominated by mobile internet devices-literature review and gap analysis. In Proceedings of the Multikonferenz. Wirtschaftsinformatik (MKWI) 2016, Ilmenau, Germany.

Hevner, A.R., S.T. March, J. Park, and S. Ram. 2004. Design science in information systems research. MIS Quarterly 28 (1): 75-105.

Hoogveld, M., and J.M. Koster. 2016. Implementing omnichannel strategies the success factor of agile processes. Advances in Management and Applied Economics 6 (2): 25. 
Hosseini, S., A. Kees, J. Manderscheid, M. Röglinger, and M. Rosemann. 2017. What does it take to implement open innovation? Towards an integrated capability framework. Business Process Management Journal 23 (1): 87-107.

Hsieh, H.-F., and S.E. Shannon. 2005. Three approaches to qualitative content analysis. Qualitative Health Research 15 (9): 1277-1288.

Hübner, A., A. Holzapfel, and H. Kuhn. 2016a. Distribution systems in omni-channel retailing. Business Research 9 (2): 255-296.

Hübner, A., J. Wollenburg, and A. Holzapfel. 2016b. Retail logistics in the transition from multi-channel to omni-channel. International Journal of Physical Distribution \& Logistics Management 46 (6/7): $562-583$.

ISO/IEC. 2010. ISO/IEC 20000-4:2010 process reference model. International Organization for Standardization Report. https://www.iso.org/standard/50624.html. Accessed 5 June 2018.

ITGI. 2009. COBIT 4.1-Control objectives, management guidelines and maturity models. Information Technology Governance Institute Report. http://www.isaca.org.ua/index.php/homepage/download/ category/2-standards?download=6:cobit-4-1-eng. Accessed 1 May 2018.

Klena, K., and L. Van Tine. 2014. Greater expectations-Consumers are asking for tomorrow, today IBM Institute for business value. http://www-935.ibm.com/services/us/gbs/thoughtleadership/ greaterexpectations/. Accessed Dec 2016.

Krueger, J. 2015. Omni-channel shoppers: An emerging retail reality. Google Inc. Report. https://www. thinkwithgoogle.com/articles/omni-channel-shoppers-an-emerging-retail-reality.html. Accessed 1 Dec 2016.

Lauchlan, S. 2017a. Burberry-meeting the omni-channel retail challenge front and back. DiginomicaArticle. https://diginomica.com/2017/05/30/burberry-meeting-omni-channel-retail-challengefront-back/. Accessed 1 Feb 2018.

Lauchlan, S. 2017b. JC Penney store closures highlight the challenge of the online/offline omni-channel retail mix. Diginomica Article. https://diginomica.com/2017/02/28/jc-penney-store-closureshighlight-challenge-onlineoffline-omni-channel-retail-mix/. Accessed 1 Feb 2018

Leeflang, P.S., P.C. Verhoef, P. Dahlström, and T. Freundt. 2014. Challenges and solutions for marketing in a digital era. European Management Journal 32 (1): 1-12.

Lehnert, M., A. Linhart, and M. Röglinger. 2016. Value-based process project portfolio management: integrated planning of BPM capability development and process improvement. Business Research 9 (2): 377-419. https://doi.org/10.1007/s40685-016-0036-5.

Lichtenthaler, U., and E. Lichtenthaler. 2009. A capability-based framework for open innovation: Complementing absorptive capacity. Journal of Management Studies 46 (8): 1315-1338.

Lundqvist, S., L. Marcusson, J. Jeansson. 2017. Activity theory applied at channel expansions in small and medium enterprises. Problems of Management in the 21st Century 12 (1): 20-38.

Luo, J., M. Fan, and H. Zhang. 2016. Information technology, cross-channel capabilities, and managerial actions: Evidence from the apparel industry. Journal of the Association for Information Systems 17 (5): 308 .

March, S.T., and G.F. Smith. 1995. Design and natural science research on information technology. Decision Support Systems 15 (4): 251-266.

McPartlin, S., and L. Feigen Dugal. 2012. Understanding how US online shoppers are reshaping the retail experience. Pricewaterhouse Coopers. http:/www.pwc.com/us/en/retail-consumer/publications/ assets/pwc-us-multichannel-shopping-survey.pdf. Accessed Dec 2016.

Melero, I., F.J. Sese, and P.C. Verhoef. 2016. Recasting the customer experience in today's omni-channel environment 1/redefiniendo la experiencia del cliente en el entorno omnicanal. Universia Business Review 50: 18-37. https://doi.org/10.3232/UBR.2016.V13.N2.01.

Miller, G.A. 1994. The magical number seven, plus or minus two: Some limits on our capacity for processing information. Psychological Review 101 (2): 343.

Ovum. 2017. Fast-forward to omni-channel management. Ovum Report.https://ovum.informa.com/ resources/product-content/huawei-whitepaper-fast-forward-to-omni-channel-management. Accessed 1 May 2018.

Pare, G. 2004. Investigating information systems with positivist case research. The Communications of the Association for Information Systems 13 (1): 57.

Parise, S., P.J. Guinan, and R. Kafka. 2016. Solving the crisis of immediacy: How digital technology can transform the customer experience. Business Horizons 59 (4): 411-420. https://doi.org/10.1016/j. bushor.2016.03.004. 
Patton, M.Q. 2014. Qualitative research and evaluation methods: Integrating theory and practice. Thousand Oaks: SAGE Publications.

Peffers, K., T. Tuunanen, M.A. Rothenberger, and S. Chatterjee. 2007. A design science research methodology for information systems research. Journal of Management Information Systems 24 (3): 45-77.

Peltola, S., H. Vainio, and M. Nieminen. 2015. Key factors in developing omnichannel customer experience with finnish retailers. In HCI in business: Second international conference, HCIB 2015, held as part of HCI international 2015, Los Angeles, CA, USA, August 2-7, 2015, Proceedings, ed. F. Fui-Hoon Nah and C.-H. Tan, 335-346. Cham: Springer International Publishing. https://doi.org/ 10.1007/978-3-319-20895-4_31.

Picot-Coupey, K., E. Hure, and L. Piveteau. 2016. Channel design to enrich customers' shopping experiences. International Journal of Retail \& Distribution Management 44 (3): 336-368.

Piotrowicz, W., and R. Cuthbertson. 2014. Introduction to the special issue information technology in retail: Toward omnichannel retailing. International Journal of Electronic Commerce 18 (4): 5-16. https://doi.org/10.2753/jec1086-4415180400.

Rauffet, P., C.D. Cunha, and A. Bernard. 2016. Managing resource learning in distributed organisations with the organisational capability approach. International Journal of Technology Management 70 (4): 300-322.

Rauffet, P., C. Da Cunha, and A. Bernard. 2012. Conceptual model and IT system for organizational capability management. Computers in Industry 63 (7): 706-722.

Rebs, T., M. Brandenburg, S. Seuring, and M. Stohler. 2018. Stakeholder influences and risks in sustainable supply chain management: a comparison of qualitative and quantitative studies. Business Research 11 (2): 197-237. https://doi.org/10.1007/s40685-017-0056-9.

Saaty, T.L. 1990. How to make a decision: The analytic hierarchy process. European Journal of Operational Research 48 (1): 9-26. https://doi.org/10.1016/0377-2217(90)90057-I.

Saaty, T.L. 2005. Theory and applications of the analytic network process: decision making with benefits, opportunities, costs, and risks. Pittsburgh: RWS publications.

Saaty, T.L., and L.G. Vargas. 2012. Models, methods, concepts and applications of the analytic hierarchy process, vol. 175. New York: Springer.

Sonnenberg C, vom Brocke J (2012) Evaluations in the science of the artificial-reconsidering the buildevaluate pattern in design science research. In: Design Science Research in Information Systems. Advances in Theory and Practice. Springer, pp 381-397.

Strauss, A., and J. Corbin. 1998. Basics of qualitative research. Thousand Oaks, CA, US: Sage Publications, Inc.

Szulanski, G., and R.J. Jensen. 2006. Presumptive adaptation and the effectiveness of knowledge transfer. Strategic Management Journal 27 (10): 937-957.

Tremblay, M.C., A.R. Hevner, and D.J. Berndt. 2010. Focus groups for artifact refinement and evaluation in design research. Communications of the Association for Information Systems 6: 1-2010.

TSO. 2012. An introductory overview of ITIL ${ }^{\circledR}$. 2011. The stationary office. http://www.bestmanagement-practice.com/gempdf/itsmf_an_introductory_overview_of_itil_v3.pdf. Accessed 22 Jan 2014.

Vaidya, O.S., and S. Kumar. 2006. Analytic hierarchy process: An overview of applications. European Journal of Operational Research 169 (1): 1-29.

Vargo, S.L., P.P. Maglio, and M.A. Akaka. 2008. On value and value co-creation: A service systems and service logic perspective. European Management Journal 26 (3): 145-152.

Verhoef, P.C., P. Kannan, and J.J. Inman. 2015. From multi-channel retailing to omni-channel retailing: introduction to the special issue on multi-channel retailing. Journal of Retailing 91 (2): 174-181.

vom Brocke, J., Simons, A., Niehaves, B., Riemer, K., Plattfaut, R., Cleven, A. 2009. Reconstructing the giant: On the importance of rigour in documenting the literature search process. In Proceedings of the 17th European Conference on Information Systems (ECIS). Verona, Italy.

Wade, M., and J. Hulland. 2004. Review: the resource-based view and information systems research: review, extension, and suggestions for future research. MIS Quarterly 28 (1): 107-142.

Walls, J.G., G.R. Widmeyer, and O.A. El Sawy. 1992. Building an information system design theory for vigilant EIS. Information Systems Research 3 (1): 36-59.

Welter, S., J.H. Mayer, and R. Quick. 2013. Improving environmental scanning systems using bayesian networks. Business Research 6 (2): 196-213. https://doi.org/10.1007/BF03342749. 
Wirtz, B.W., and P.F. Langer. 2016. Public multichannel management-An integrated framework of offand online multichannel government services. Public Organization Review 17 (4), 563-580.

Yin, R.K. 2013. Case study research: Design and methods. Thousand Oaks: Sage publications.

\section{Publisher's Note}

Springer Nature remains neutral with regard to jurisdictional claims in published maps and institutional affiliations. 